\title{
Research
}

\section{Using Coupled Simulation Models to Link Pastoral Decision Making and Ecosystem Services}

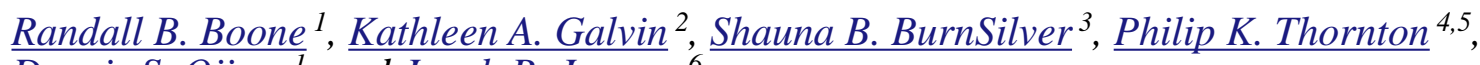 \\ $\underline{\text { Dennis S. Ojima }}^{1}$, and Jacob R. Jawson ${ }^{6}$
}

\begin{abstract}
Historically, pastoral people were able to more freely use the services their semi-arid and arid ecosystems provide, and they adapted to changes in ways that improved their well-being. More recently, their ability to adapt has been constrained due to changes from within and from outside their communities. To compare possible responses by pastoral communities, we modeled ecosystem services and tied those services to decisions that people make at the household level. We created an agent-based household model called DECUMA, joined that model with the ecosystem model SAVANNA, and applied the linked models to southeastern Kajiado District, Kenya. The structure of the new agent-based model and linkages between the models are described, and then we demonstrate the model results using a scenario that shows changes in Maasai well-being in response to drought. We then explore two additional but related scenarios, quantifying household well-being if access to a grazing reserve is lost and if access is lost but those most affected are compensated. In the second scenario, households in group ranches abutting the grazing reserve that lost access had large declines in livestock populations, less food energy from animal sources, increased livestock sales and grain purchases, and increased need for supplemental foods. Households in more distant areas showed no changes or had increases in livestock populations because their herds had fewer animals with which to compete for forage. When households neighboring the grazing reserve were compensated for the lease of the lands they had used, they prospered. We describe some benefits and limitations of the agent-based approach.
\end{abstract}

Key Words: Agent-based modeling; DECUMA household model; ecosystem services; livestock; Maasai; mobility; pastoral decision making; SAVANNA ecosystem model

\section{INTRODUCTION}

For millennia semi-arid and arid lands have supported wildlife, livestock, and the people who rely on those animals. Decisions by pastoral people have been influenced by factors such as forage quality and quantity, water sources, and fuel wood availability - which are more broadly labeled as ecosystem services (Daily 2000, Daily and Matson 2008) — while contending with stressors such as droughts, livestock raids, and changing markets. During the twentieth century, the ability of pastoral people to respond to stressors began to erode. Fragmentation and changes in land use and land tenure limited movements by wild and domestic ungulates (Behnke et al. 1993, FAO 2001) and reduced animal forage (Boone et al. 2005), and human and wildlife conflicts have increased (Browne-Nuñez and Jonker 2008). In Africa, human population growth severely limited the capacity of pastoralists to respond to stressors (Fratkin and Smith 2005). The twenty-first century will bring to semi-arid and arid systems unprecedented climate change, at least within human history (IPCC 2007), thus further stressing these systems.

What are the best ways for pastoral people to respond to new stressors? A main means of addressing the question quantitatively is through scenario analyses using computer simulations (Galvin et al. 2004, 2006, Peck 2004). Baseline simulation results representing a stylized version of

\footnotetext{
${ }^{1}$ Natural Resource Ecology Laboratory and the Department of Forestry, Rangeland, and Watershed Stewardship, Colorado State University, ${ }^{2}$ Department of Anthropology and the Natural Resource Ecology Laboratory, Colorado State University, ${ }^{3}$ Agricultural and Forestry Experiment Station, University of Alaska, International Livestock Research Institute, ${ }^{5}$ University of Edinburgh, ${ }^{6}$ Department of Forestry, Rangeland, and Watershed Stewardship, Colorado State University
} 
current conditions are compared to simulation results where ecosystem services have been altered, or where the adaptive capacity of households has changed.

In past research we simulated how changes in ecosystem services would affect pastoral household well-being (Thornton et al. 2003, 2006; Galvin et al. 2004, 2006; Bulte et al. 2008). However, the household model used, called PHEWS, was population based, meaning that households were placed into a few groups using a classification we assigned (i.e., wealthy livestock owner; poor livestock and business owner). Three main restrictions arose from this approach. First, the topdown assignment of households yielded results at a given scale, and responses at finer scales could not be explored. Second, households could not shift between categories as their conditions changed, such as changing wealth levels. Third, and perhaps most importantly, because the finest representation of households were as members of these classification groups, households had no spatial location, and so the decision making of households could not be linked to conditions in their environments.

In this work, we sought a bottom-up organization of households. We chose a spatially explicit agentbased approach, where autonomous interacting agents make decisions based on their environmental and socioeconomic conditions and on a set of rules or processes (Epstein 1999, Bonabeau 2002, Evans and Manson 2007). Specifically, we chose an empirical agent-based approach (Janssen and Ostrom 2006), where agents were households simulated to represent stylized real responses. Existing models of households in rangelands were simpler than we required, dealt primarily with land cover change, were not spatially explicit, were not appropriate to link to our ecosystem model, or did not track food energy and monetary flows (e.g., Parker et al. 2003, Evans and Kelley 2004, Castella et al. 2005, Kuznar and Sedlmeyer 2005, Gross et al. 2006, Milner-Gulland et al. 2006, Cioffi-Revilla et al. 2008). We therefore constructed a suitable model.

In our study, we used two linked models to represent coupled natural and human systems, a longestablished ecosystem model, and the new agentbased model. Our primary purpose is to introduce our approach to simulation of coupled natural and human systems, our agent-based model, and the methods we used to link that model to an ecosystem model. The agent-based model and the linkage of the two models are novel contributions, and are described in more detail than the ecosystem model. The household model is described using the ODD protocol (Grimm et al. 2006; Polhill et al. 2008). We reviewed a baseline simulation and assessed results by comparing them to observed patterns. We contrasted results from a baseline simulation with those from a simulation that included a new drought. Lastly, we used the coupled agent-based household and ecosystem models to simulate a scenario (Thornton et al. 2006) that we explored using the population-based household model. In that scenario, a high-elevation key resource area now used as a grazing reserve was converted to rain-fed agriculture. We discuss some advantages and disadvantages of each modeling approach, and interpret our results in light of Maasai household well-being.

\section{STUDY AREA}

Kajiado District is a semi-arid region in southwestern Kenya (Fig. $1 ; 36^{\circ} 0^{\prime} \mathrm{E}$ to $37^{\circ} 55^{\prime} \mathrm{E}$, $1^{\circ} 1^{\prime} \mathrm{S}$ to $3^{\circ} 3^{\prime} \mathrm{S}$ ) which is inhabited by Maasai pastoralists and others. Our study area is the southeastern half of the district (Fig. 1), an area of $10746 \mathrm{~km}^{2}$. Amboseli National Park is near the center of the study area, and on the eastern border is the West Chyulu Game Conservation Area (Ole Katampoi et al. 1990). Precipitation is variable over space and time, but sums to between 400 and 800 $\mathrm{mm}$ annually, with the higher amounts occurring on slopes. The landscape supports diverse grasslands, extensive bushlands, five large swamps, and scattered Acacia woodlands, with some forests. Diverse wildlife populations inhabit the park during the dry season, and move into neighboring grazing lands in the wet season.

We estimated there were 52000 people in the study area in 2002 (Thornton et al. 2006). Livestock raising remains the primary contributor to livelihoods, but Maasai have diversified (BurnSilver 2007). In essence most residents are agropastoralists, doing high-risk rain-fed cultivation of maize and beans on small plots. Others do more intensive irrigated cultivation in or adjacent to the swamps. Household members own small-scale businesses, and wages comprise a major income source for some Maasai households. The district remains monetarily poor (Government of Kenya 2003 ), with rates of poverty varying from 11 to $68 \%$ of the population (Thornton et al. 2006); people 
Fig. 1. Southern Kajiado District, Kenya, with the six study areas labeled, as well as Amboseli National Park and the Chyulu Hills. Locations of the 184 households surveyed are marked with open circles. Topography is shown in gray, from the Shuttle Radar Topography Mission, and the location of Kajiado District within Kenya and Africa is shown in the insets.

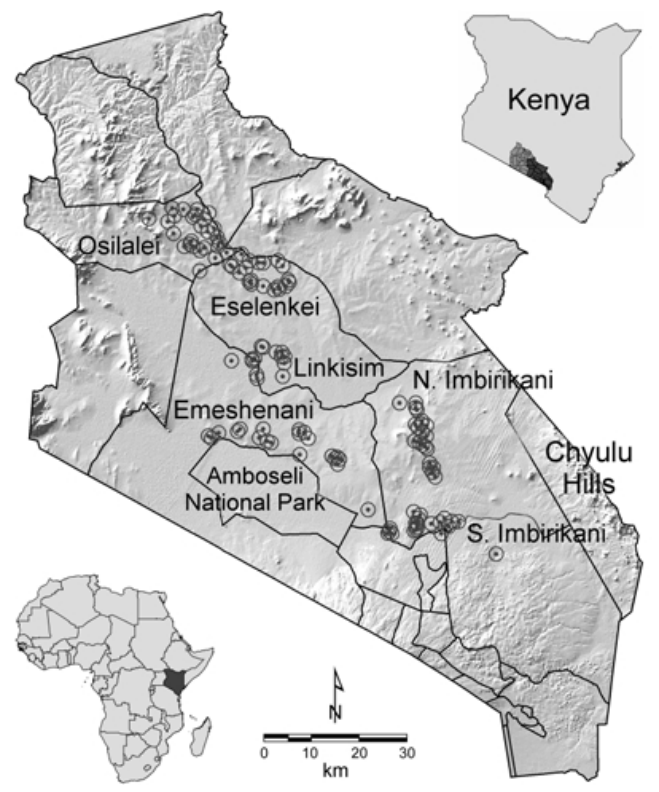

were classified as in poverty if a person earned $<1239$ Kenyan shillings (KSh) per adult per month, which is roughly equivalent to US\$16.

BurnSilver (2007) and Worden (2007) surveyed six Maasai communities that differed in their history of land subdivision, and those surveys inform our household simulation model. We sought to model all households within the study area, but household survey data (Fig. 1) were for: (1) Osilalei Group Ranch; (2) Eselenkei study area, in the northern portion of the group ranch with that name; (3) Linkisim, in the southern part of that group ranch; (4) Emeshenani, which is in Olgulului/Lolorashi Group Ranch and abuts Amboseli National Park; and (5) northern and (6) southern portions of Imbirikani Group Ranch.

\section{METHODS}

To link the mutual influences between households and ecosystem services through space and time required a spatially explicit ecosystem model, a household model appropriate for linkage to the ecosystem model, and information sufficient to allow the models to be parameterized and assessed. As an ecosystem model, we used SAVANNA, which has been useful in past work in the study area (Boone et al. 2005, Thornton et al. 2006, Boone 2007, Boone and Wang 2007). We constructed DECUMA (DEcisions under Conditions of Uncertainty by Modeled Agents) as a spatially explicit household model.

\section{SAVANNA ecosystem model}

Development of the SAVANNA model began more than 20 years ago, while its author M. Coughenour worked in the Turkana region of Kenya (Coughenour 1985). Since that time, the model has been updated and applied throughout the world (e.g., Coughenour 1992, Eastman et al. 2001, Christensen et al. 2004, Boone et al. 2006, Thornton et al. 2006, Boone and Wang 2007). SAVANNA is a series of connected FORTRAN modules that simulate ecosystem processes through time in a spatially explicit way. Landscapes are divided into cells, and digitized maps inform SAVANNA of the 
attributes of cells. Weather data for stations are used to interpolate monthly temperature and precipitation surfaces for the study area. During a simulation, plant functional groups within each landscape cell compete for light, nutrients, water, and space. During any time-step, plants in functional groups may grow, may reproduce, and may die, either through baseline death rates or stresses such as drought and extreme temperatures. The death of plants in one functional group may allow another group to expand its proportion of cover on a cell. Wild herbivores are represented in SAVANNA as populations. Herbivores feed on plants according to diets that are specified. Wild herbivores gain energy from the food they consume, and expend energy through basal metabolism, travel, gestation, and lactation. Excess energy is put to weight gain, and an energy deficit leads to weight loss. Wild animal population dynamics are simulated.

SAVANNA simulates ecosystems using a weekly time-step, with spatial and temporal summations produced each month. Simulations span from 10 to 50 years or more, and can simulate small areas or areas up to many thousands of square kilometers. More detail is available in Ellis and Coughenour (1998) and Boone et al. (2005).

\section{DECUMA household model}

The household model description follows the ODD protocol for describing agent-based models (Grimm et al. 2006, Polhill et al. 2008), which includes seven regular elements that provide an overview, design concepts, and details of the model.

\section{Purpose}

DECUMA simulates decision making and behaviors by pastoral household heads as they relate to ecosystem services. Measures reflecting the wellbeing of household members, such as livestock dynamics and holdings, energy flows, and cash flows, are tracked. DECUMA links to an ecosystem model that quantifies ecosystem services (e.g., forage availability) and can simulate effects of grazing by livestock on services.

\section{State variables and scales}

The attributes of individual households are defined by state variables such as number of members, livestock holdings, incomes and expenses, and geographic location (Table 1, Appendix 1 provides an example based on a household interviewed). Decision making is influenced by a series of parameters common across households that capture attributes such as energy requirements, and adultequivalency values, prices of animals bought and sold, and parameters reflecting the likelihood of seasonal movement by households (Appendix 2, with entries based on the literature or averaged responses from households surveyed). Households interact with other households through competition for grazing resources and by gifting of livestock. A weekly time-step is used to simulate livestock dynamics and energy acquisition, and a monthly time-step is used for birthing and aging of livestock herds, and for household decision making. There is no intrinsic spatial scale associated with DECUMA, as that is provided by the ecosystem model to which the agent-based model is joined. In the application to southeastern Kajiado District, Kenya, the gridded landscape cells represented areas $2.5 \times 2.5 \mathrm{~km}$, with $10746 \mathrm{~km}^{2}$ simulated. Results may be summarized for all households within arbitrarily defined subareas, or for the entire area simulated. Spatial and temporal results are produced monthly, and simulations typically represent from about 10 to 50 years. Here, simulations spanned 24 years.

\section{Process overview and scheduling}

Process may be grouped into four broad categories, those that simulate (1) livestock distribution and dynamics, (2) household decision making and flows, (3) initialization, and (4) input/output. Here we focus on the first two. Livestock processes include: distribution of animals of simulated species, based on forage availability provided by the ecosystem model and on the locations of households and rules of access; energy acquisition, based on the amount of forage acquired given the distribution of the livestock; energy use; weight change, which is based on the difference between energy acquired and energy used; and population dynamics, with birth rates and death rates related to a ratio of current and expected body mass.

Household modeling includes the following processes: energy flows, where caloric gains from foods eaten are tallied and compared to energy needs; cash flows, which includes regularly scheduled income and expenses, as well as shortterm sales or purchases; crop harvest; livestock trading; a calculation of cash needs three months into the future, which is used in decisions about 
Table 1. State variables of households represented in the DECUMA model. Variables are grouped into classes for clarity. These variables are assigned initial values only. Livestock populations, the cashbox, assets, and debts may change during a simulation. Milk income depends on the number of lactating cattle in the household herd. Other attributes of the household do not change during a simulation.

\begin{tabular}{llll}
\hline \hline Attribute & class & Units & Notes \\
\hline General & & & \\
& ID & Number & A unique identifier \\
& People & Number & Age and sex classes \\
& Location & Meters & X and Y coordinates
\end{tabular}

Livestock

$\begin{array}{lll}\text { Cattle } & \text { Number } & \text { By sex } \\ \text { Goats } & \text { Number } & \text { By sex } \\ \text { Sheep } & \text { Number } & \text { By sex }\end{array}$

Agriculture

Irrigated

Rain-fed

Highland

Incomes

Wages
Livestock trading
Business
Milk sold

Expenses

Household goods

School fees

Crop inputs

Veterinary inputs

Other
Acres

Acres

Acres

Shillings

Shillings

Shillings

Percent

Shillings

Shillings

Shillings

Shillings
Swamp agriculture

Upland agriculture

Slopes of Kilimanjaro

Hourly wages

Petty trade and business

Of total produced

Tea, sugar, etc.

Seed, fertilizer, etc.

Medicines, supplies
Cashbox

Assets

Debt
Shillings

Shillings

Shillings 
livestock trading; gifting; and mobility of camps, where herders decide whether to move their temporary camps.

Regarding scheduling, after the model initializes, a monthly cycle begins. Herders weigh the ecosystem services, especially forage quality and quantity, at their current location and at a set of randomly selected alternate locations, and may decide to move if the anticipated benefits (energy acquisition) outweigh the costs (e.g., travel costs, distance to water, being away from the home group ranch). A weekly cycle of livestock grazing is then modeled. Livestock are distributed on the landscape based on habitat suitability, then the energy the animals acquire from grazing in that distribution is summarized, and livestock status is updated. The monthly cycle then resumes. The energy acquired by livestock and energy costs are used to model changes in body mass. Condition indices are updated, which are scores from 0 to 1 that compare simulated to expected body masses. Mortality is then simulated, with condition indices of animals having an effect on their mortality rates. At the appropriate month females give birth, again with the condition of animals influencing rates, and at the end of the year livestock are aged.

Crops are harvested if the month simulated matches the month assigned for the crop. The primary sources of household income (e.g., crop sales, milk sales, wages) and expenses (e.g., food, schooling, veterinary care) for each household are reckoned to yield monetary flows and holdings. The model calculates the money each family may need in the following three months, based on predictable expenses. That information is used by the household to decide if a cow, goat, or sheep should be sold (Thornton et al. 2003). The model then tracks food energy acquired by each household, including from milk, home-grown maize, edible dead animals, meat eaten during ceremonies, and sugar in tea. If a deficit in energy still exists and the household members can afford to, they buy maize. If a shortfall still remains and more livestock cannot be sold, it is filled through supplemental relief from neighbors or international aid agencies (Thornton et al. 2003). If household members have ample money in reserve, they may buy an animal. Animals are bought from, or sold into, an unlimited pool of animals outside the simulated area. Finally, a few animals of a given species may be given by wealthy families to families who have lost their herd of that species (Huysentruyt et al. 2009). The model then continues simulating the next month.

The main processes and connections in the model are shown in Fig. 2, including processes simulated in the ecosystem model. Appendix 3 provides the main controlling program of DECUMA, showing the explicit scheduling in the model, with each line annotated.

\section{Design concepts}

Simulation flow. A major design concept was the need to link DECUMA with ecosystem models. In linking with SAVANNA, soils, vegetation, and wildlife are simulated as in past applications (Coughenour and Singer 1996). For livestock, SAVANNA and DECUMA share information weekly in the following process (Fig. 3):

1. SAVANNA calculates, for each cell and each livestock species, a habitat suitability index, and writes that in matrix form to an ASCII text file. The habitat suitability values incorporate forage quality, quantity, slope, elevation, temperature, woody cover, the density of wild animals, and distance to water. SAVANNA then pauses.

2. DECUMA reads that file, and converts those suitability measurements to maximum livestock density estimates using a linear conversion (Van Horne and Wiens 1991). Based on the locations of household herds and a grazing radius, rules of access, tenure restrictions, institutional norms, habitat suitability values, and densities of animals already placed, livestock are distributed on the landscape. Those matrices, representing the numbers of livestock grazing on each grid cell, are written to file and DECUMA pauses.

3. SAVANNA reads these data and continues with the simulation of that weekly time-step.

4. SAVANNA calculates for each grid cell the metabolizable energy that livestock species acquired (MJ animal day $^{-1}$ ) while grazing during the time-step, and these data are stored for use by DECUMA.

5. DECUMA then tracks livestock energy dynamics. Each herd is represented by a 
Fig. 2. Primary information flows within the household decision-making model DECUMA and the ecosystem model SAVANNA, and flows between the models. See the Methods for a discussion of these flows.

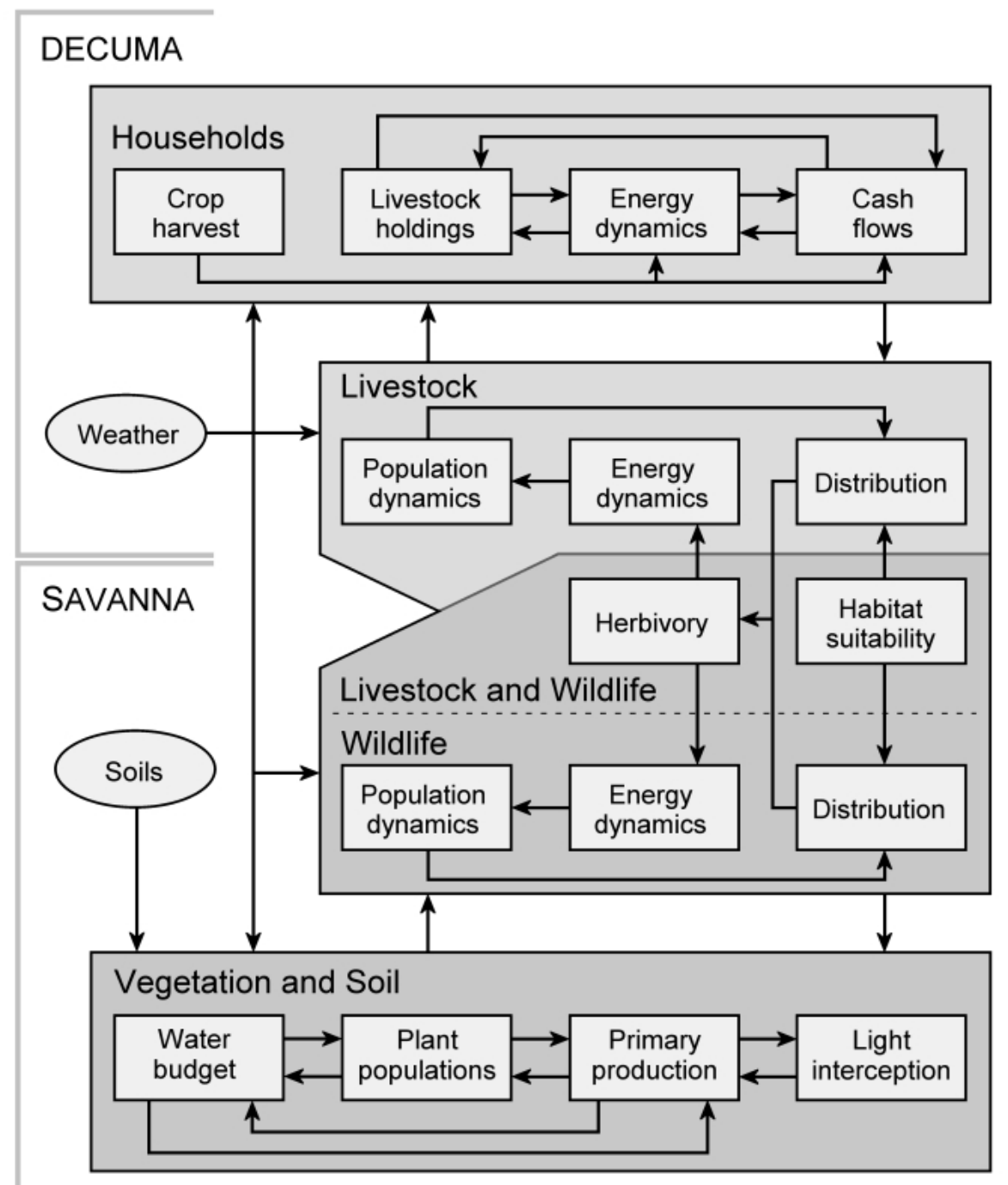

Leslie matrix with age and sex cohorts (Leslie 1945, 1948), and expected body mass of each age-sex class is calculated using Brody curves (Brody 1945). If it is the end of a month, energy needs are compared to energy acquired, and weight change is simulated. Mortality of livestock, livestock birthing (if the appropriate month), and the steps involving agent decision making and tallying of gains and expenditures, occurs. The cycle then repeats from step 1.
Adaptation. Our primary interest is in the adaptive capacity of pastoral people under stressors such as changes in policy, land tenure, access, and climate. The main means that pastoralists can adapt in the model is through the changing areas where they graze their animals, longer term mobility through the use of temporary camps, livestock trading, and the purchase of maize.

Prediction. Agents make a form of prediction in two ways in DECUMA. First, households know their scheduled incomes and expenses for the coming 
Fig. 3. Detailed information flows between the household decision-making model DECUMA and the ecosystem model SAVANNA. Numbers are cited within the Methods.

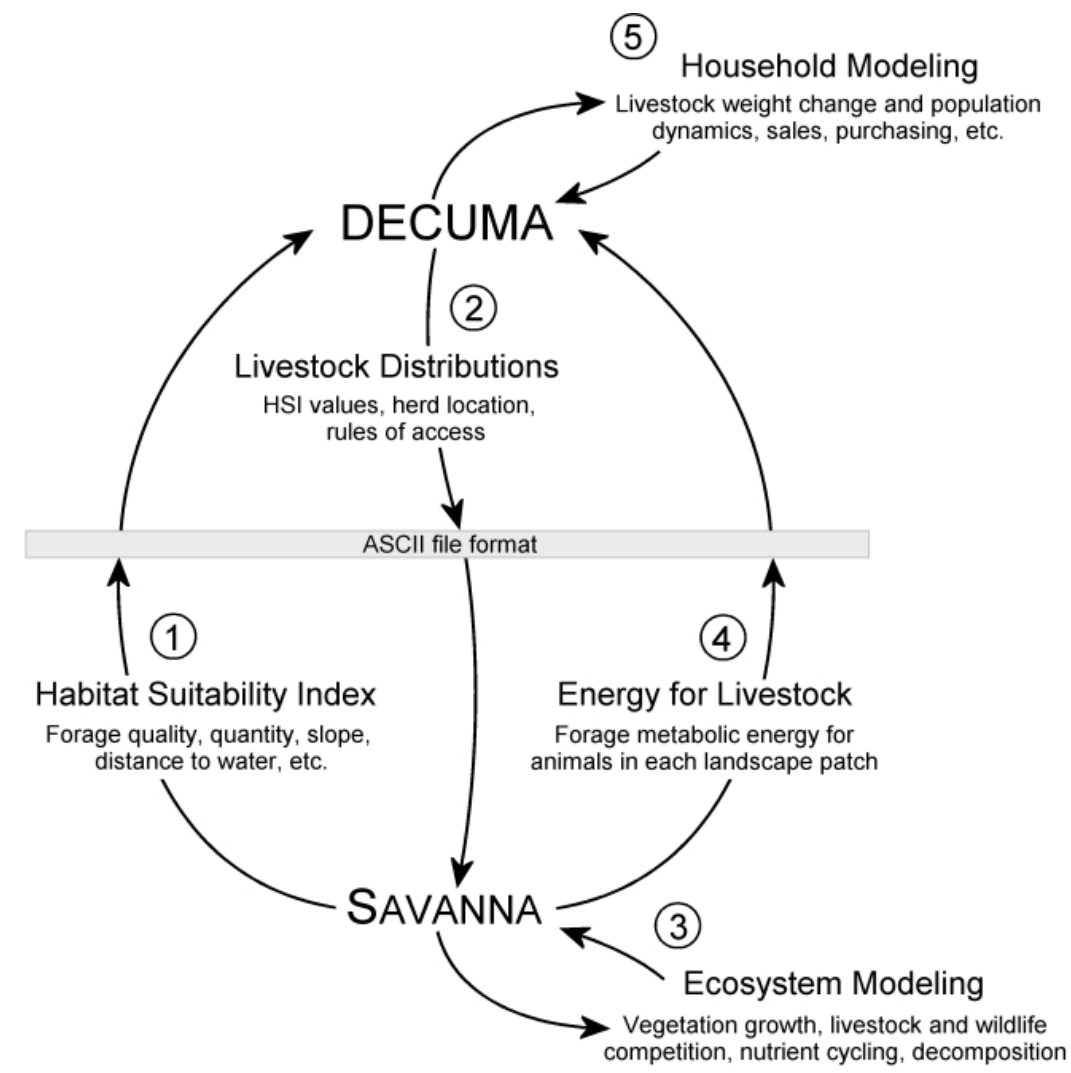

months (e.g., Appendix 1). Households anticipate known cash needs three months into the future, and use that information in livestock trading; if more money is needed over the next three months than is held, they are more likely to sell an animal. The second form of prediction of future conditions is through use of long-term habitat suitability surfaces. These surfaces are the average habitat suitability of areas for each species throughout the simulation. They capture long-term forage availability expectations and are used by agents when deciding whether or not to move.

Sensing. Household herders sense the habitat suitability within a distance defined as the grazing orbit around their current location (e.g., $10 \mathrm{~km}$ ). Sensing also occurs over the entire area when herders consider moving their temporary camps, i.e., when the benefits from moving to 10 sites selected randomly from the area are weighed. This long-range sensing reflects the sharing of news about grazing conditions, which is a common pastime in the community.
Stochasticity. The order in which herders decide where to graze their animals is relevant, because those who decide first have the best grazing areas to select from. Detailed political and power relationships are not available to us, and so we used a newly randomized order of selection each week (as in Milner-Gulland et al. 2006).

Observation. For each simulation, DECUMA produces tabular files that store attributes averaged across households. Another tabular file saves monthly data for individual households, i.e., for a subset of households a user selects. The model also produces spatial data, which includes permanent and temporary camp locations each month, habitat quality for each livestock species, and livestock distributions. Some output uses standardized measures for livestock and humans; tropical livestock units (TLU), with one unit equal to 250 $\mathrm{kg}$ body mass of livestock; and adult equivalents (AE), where adult males were assigned an AE of 1 , and adult females and younger people were assigned smaller values (see Appendix 2). A graphical user 
interface created using Visual Basic 6 (Microsoft Corp., Redmond, Washington, USA) runs the linked DECUMA and SAVANNA models, and creates charts and maps of user-selected output as a simulation progresses.

\section{Initialization}

Initial attributes for households were set using the conditions of the surveyed household that was geographically nearest to the location selected for the new house and in the same region. Attributes initialized for each household are summarized in Table 1 and an example is provided in Appendix 1. To avoid a long period of unstable responses at the start of each simulation, a "spin-up" simulation of 60 years was made for all the households, and then their conditions were stored to a computer file. This spin-up used randomized years of weather data from 1973 to 2002. During subsequent simulations, this file was read, and conditions for households were set to those in the file. The initial conditions of the surveyed households were then reset to the observed values, and simulations commenced.

\section{Input}

DECUMA reads a series of maps and parameter files that describe the study area and household attributes, including maps delineating the study area, household densities, slope, distances to water sources, and the subareas of interest. Appendices 1 and 2 provide example parameter files. Three files provide age distribution, energy, and population parameters for each livestock species simulated. DECUMA does not use other dynamic input directly, but the ecosystem model to which DECUMA is linked uses dynamic precipitation and temperature data.

\section{Submodels}

DECUMA is composed of a series of submodels programmed in FORTRAN 95. The primary submodels are described more fully in Appendix 4.

\section{SAVANNA-DECUMA modeling in southern Kajiado}

SAVANNA and DECUMA were parameterized to emulate conditions during the period when household interviews were gathered (1999 to 2000), to the degree possible. Seven plant functional groups are represented (i.e., palatable grass, palatable forbs, unpalatable herbs, swamps, palatable shrubs, unpalatable shrubs, and woodlands, as in Boone et al. (2005)). Six wild herbivore functional groups are included (wildebeest (Connochaetes taurinus), zebra (Equus quagga), African buffalo (Syncerus caffer), grazing antelope, browsing antelope, and elephant (Loxodonta africana)). Species included in the antelope groups and example citations used in parameterizing the model are in Boone (2005). In general, SAVANNA-DECUMA represents land cover types spatially, but cultivation is non-spatial (i.e., area cultivated is an attribute of households; Table 1, Appendix 1). Cultivation by Maasai households is at relatively small scales (i.e., $<1$ ha on average), but landscapes were represented by 2.5 x $2.5-\mathrm{km}$ cells (i.e., $6.25 \mathrm{~km}^{2}$ or $625 \mathrm{ha}$ ), making a spatial representation of cultivation impractical. Simulations reported here use precipitation and temperature from 1980 to 2003, with years labeled 1 to 24 in the figures.

We simulated 3820 households (Thornton et al. 2006). Detailed survey data for 184 of those households were available (BurnSilver 2007, Worden 2007). Household densities were mapped using census and ancillary data (Thornton et al. 2006). We distributed the 3820 households by pseudo-randomly selecting locations based on the densities in that map. The households were then initialized as described above.

Assessing results from integrative simulations such as this is particularly difficult (Thornton et al. 2003); the utility of the results to researchers and stakeholders becomes paramount (Rykiel 1996). We would prefer to have an extensive, unique set of household survey data to compare with, but those data are not available. Our best observed data are the household surveys used to initialize our model. With six subareas in the simulation, and given the variability between households, we chose not to reserve some of the data for assessment. Patternoriented assessment (Grimm et al. 2005) suggests that the agreement of results to multiple patterns at different scales can help in assessment. We therefore compare our simulated results over time to patterns in the household survey data and to community-level patterns (e.g., poverty rates).

\section{Scenarios}

In the first scenario, we looked at the effects of a 2yr drought on households and the ecosystem. Drought was used because its primary effects on 
semi-arid and arid landscapes are widely known. In the weather data, we selected a period of typical rainfall (1985 to 1986) and decreased precipitation to equal the mean of precipitation $(550 \mathrm{~mm})$ minus twice its standard deviation $(150 \mathrm{~mm}$; following Galvin et al. 2004). In our second scenario, we emulated a setting where access by the Maasai to a key resource, the Chyulu Hills dry season grazing reserve, was lost and households were not compensated, such as may occur if the Kenyan government chooses to use those lands for wheat production. Our third scenario is related, but with the Maasai leasing their lands for wheat production, and receiving compensation (as in Thompson and Homewood 2002).

As in reality, changes in livestock populations and household responses are sensitive to climatic patterns. Our drought scenario focuses on the observed and modified weather pattern, and so we used those data in two simulations. For our scenarios regarding access in the Chyulu Hills, climatic variability was not our focus, so we conducted 50 simulations for each scenario, using a unique random ordering to annual weather data in each simulation, 25 for the baseline model, and 25 with access denied.

In our third scenario, the Chyulu Hills, were leased from members of the neighboring group ranches. We appreciate Thompson and Homewood's (2002) message that benefits to group ranch members from external sources are not evenly distributed because of power and access imbalances and graft. However, those relationships are notoriously opaque, and were not available to us. Here, each member received the same benefit. In ranches in Narok District, Kenya where lands were leased to wheat cultivators, ranch members made on average US $\$ 25$ $\mathrm{ac}^{-1} \mathrm{yr}^{-1}$ (Thompson and Homewood 2002:129). The Chyulu Hills have a similar agro-climatic potential as the lands in Narok (Ole Katampoi et al. 1990, drawing on Braun 1980, Thompson and Homewood 2002), and so we adopted this value. Based on the area of the Chyulu grazing reserve (81 250 ha or $200773 \mathrm{ac}$ ) and numbers of households who were members in the two group ranches that abutted Chyulu, we calculated monthly income to each Imbirikani and Kuku household would be $2490 \mathrm{Ksh}$, or US\$34.58/month, using the exchange rate of 72 $\mathrm{Ksh} / \mathrm{US}$.

Average responses for the 184 focal households from DECUMA were calculated. For the scenarios regarding changing access to the Chyulu Hills, responses from the baseline model using one of the randomized weather files were subtracted from the matching simulation where access was altered. This yielded differences in responses with the expected sign from the paired simulations. We then calculated averages and standard errors using SYSTAT Ver. 11 (2004; Chicago, Illinois, USA) and created figures. One-sample t-tests were used to compare mean differences in responses across our 184 households to no change in responses (i.e., mean = 0 ). Bonferroni adjustments were made for multiple comparisons. Our results emphasize DECUMA output, in order to demonstrate the new model.

\section{RESULTS}

\section{Baseline simulation}

Bounded baseline responses are a type of assessment, in so far as keeping the numerous responses in DECUMA concurrently reasonably bounded while maintaining responsiveness to stressors such as drought is non-trivial. Comparing our baseline results (Fig. 4) to observed patterns at the scale of households, we simulated slightly fewer livestock per person than were observed among the 184 households surveyed (BurnSilver 2007:48), and with greater variability across households (5.6 TLUs/AE, SD 11.4 versus 6.3 TLUs/AE, SD 6.7). Total livestock populations were stable, but there was a gradual increase in the amount of supplemental relief required by households, a decline in milk and meat energy acquired, a slight increase in the number of animals sold over time, and an increase in energy that was purchased (Fig. 4). The number of movements to temporary camps was in line with observed rates, and greater in 2000 , a year of drought, than in 1999 (observed, 2.2 and 2.7 in 1999 and 2000; simulated, 2.6 and 2.7). Income across the households was in close agreement, with US\$1583 earned on average in surveys (BurnSilver 2007:53) and US\$1572 in simulation. At a broader scale, poverty rates in Kajiado are high (i.e., incomes below US\$16 month $^{-1} \mathrm{AE}^{-1}$ ) (reviewed in Thornton et al. 2006). In the base simulation, average monthly income per $\mathrm{AE}$ is US\$9.70, with high variation (SD US\$5.32). 
Fig. 4. Selected DECUMA responses, comparing the baseline simulation with observed weather data (circles) to responses when a 2-yr drought (triangles) ocurred in Years 6 and 7 of the simulation. The responses in panels "b", "d", "e", and "f" are per month, and those in panel "c" are per year. Panel "a" includes standardized measures for livestock and humans, tropical livestock units (TLU, with one unit equal to $250 \mathrm{~kg}$ body mass of livestock), and adult equivalents (AE, where adult males were assigned an $\mathrm{AE}$ of 1, and adult females and younger people were assigned smaller values) (see Appendix 2 for AEs used).

a.

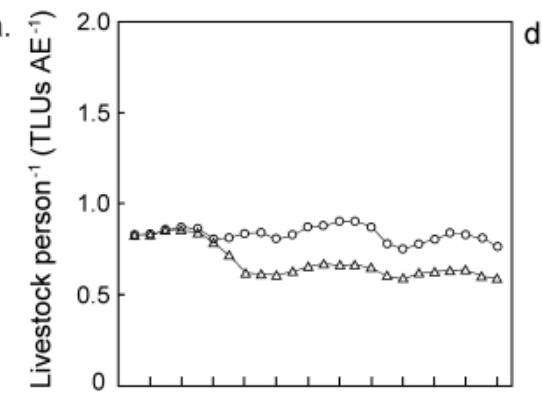

b.

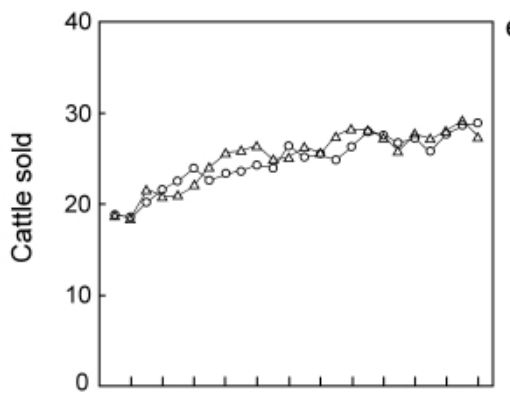

c.

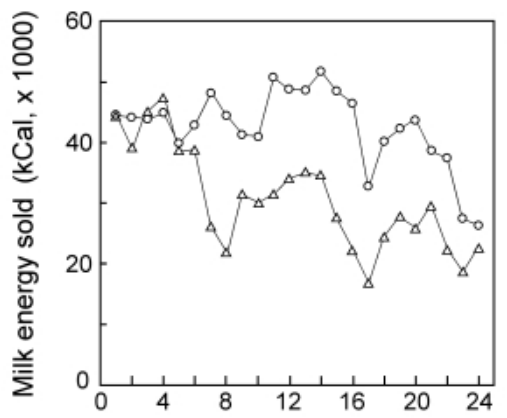

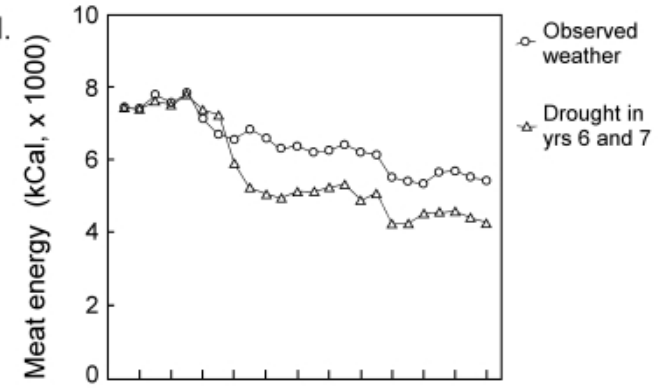
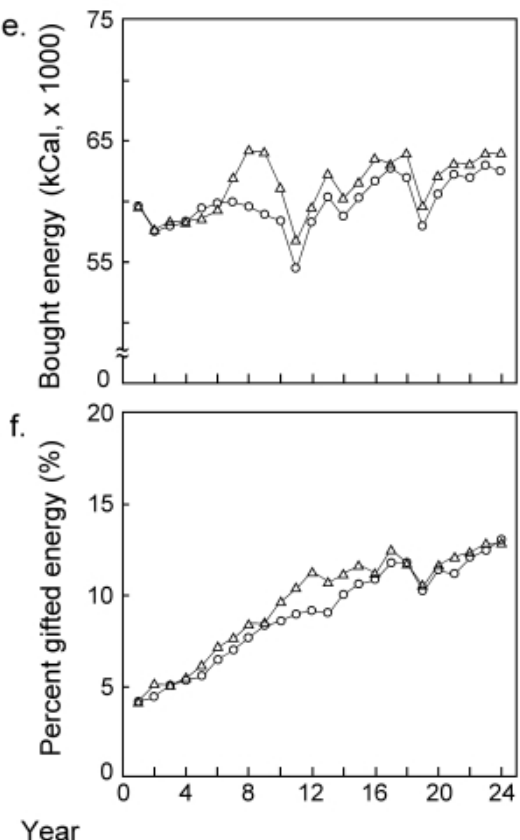

\section{Effects of drought}

In the scenario results, effects of drought on Maasai livestock and well-being are longer-lived than may be anticipated (Fig. 4). This does not reflect rangeland degradation, although that occurs in the short term, but rather the steps non-wealthy Maasai must take to meet their caloric needs. The severe drought decreased livestock numbers (Fig. 4a), which reduced animal-source foods for household members (Fig. 4c and d). Drought also eliminated rain-fed maize production for the households, thus further reducing food security. Households without monetary stores had to then sell livestock (Fig. 4b) to purchase grain (Fig. 4e), and the shortfall was made up with supplemental gifted relief (Fig. 4f). The sale of livestock in turn led to less food available in the next month, and the process continued as a positive feedback loop, yielding a downward spiral sometimes seen in reality (Rutten 1992, Boone et al. 2005). These linked responses highlight the interconnectedness of the DECUMA model. Individual household responses may be compared given the agent-based focus. For example, shifts in 
Fig. 5. The number of individual households with cattle holdings in bins (with varying dimensions when scaled to $\log 10$ ), of the 184 with results reported in detail. The histogram shows the baseline holdings (light bars) and holdings in July following a two-year drought (dark bars). Drought conditions reduced livestock holdings, and essentially shifted the density histogram toward lower values.

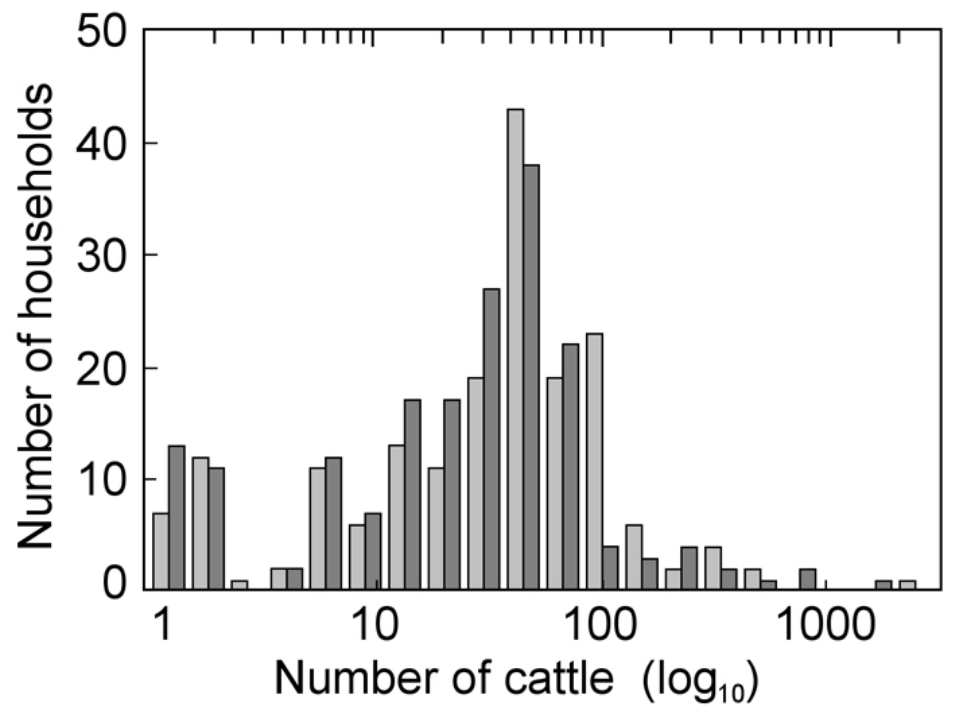

cattle holdings (Fig. 5) and investigation of individual household responses confirm that although most households lost animals in drought some increased their herds, due to reduced competition for forage.

\section{Changes in access and compensation}

Loss of access to the Chyulu Hills grazing reserve by Maasai herders caused a decline in the number of livestock per person in the Imbirikani study areas, Emeshenani, and Linkisim (Fig. 6a and b, left column). These declines may appear modest, but represent about a $25 \%$ decline in numbers of animals owned by households in Northern Imbirikani, which would be severe for households already experiencing food insecurity. In Eselenkei, livestock populations declined initially, but later increased when competition for forage lessened as herds in the areas closer to the Chyulus declined. Herders from near the Chyulu Hills had fewer animals they could bring to Eselenkei during the dry season, thus reducing competition and benefiting the local livestock. These responses are tempered because herders in Eselenkei and Osilalei lost access to the Chyulus during severe drought, as did the other households in the study area. When households in Imbirikani Group Ranch were compensated for their loss of access to the Chyulu Hills, they prospered. Households in Imbirikani purchased additional animals, but also avoided having to sell animals to purchase grain (Fig. 6a, right). Livestock populations in the remaining areas did not change markedly (Fig. $6 a$ and b). This further demonstrates the value of place-based simulation of agents, where those living near the Chyulus could increase their herds using compensation, but they could not support an unlimited number of animals on the wet season forage available around their permanent households. Too few animals were moved to Eselenkei and the other more distant areas in the dry season to cause population declines in the herds of the households that lived there. Changes in other measures of household well-being as access to the Chyulu Hills was lost are summarized in Table 2 , with significant differences noted.

\section{DISCUSSION}

Our results demonstrate that the linked DECUMA and SAVANNA models simulate the coupled human and natural Kajiado ecosystem reasonably, with baseline responses for the households for which we have survey data remaining reasonable 
Fig. 6. Changes in livestock per person, using standardized metrics, when livestock herders were unable to access the Chyulu Hills (left panels), and when access to the Chyulu Hills was not available but herders in neighboring group ranches were compensated for the leased land (right panels). Changes in three areas are shown in rows "a" and "b", divided only for visual clarity. Row "a" includes Emeshenani (EM, circles), Northern Imbirikani (NI, triangles), and Southern Imbirikani (SI, squares). Row "b" includes Eselenkei (ES, circles), Linkisim (LK, triangles), and Osilalei (OS, squares).

a.
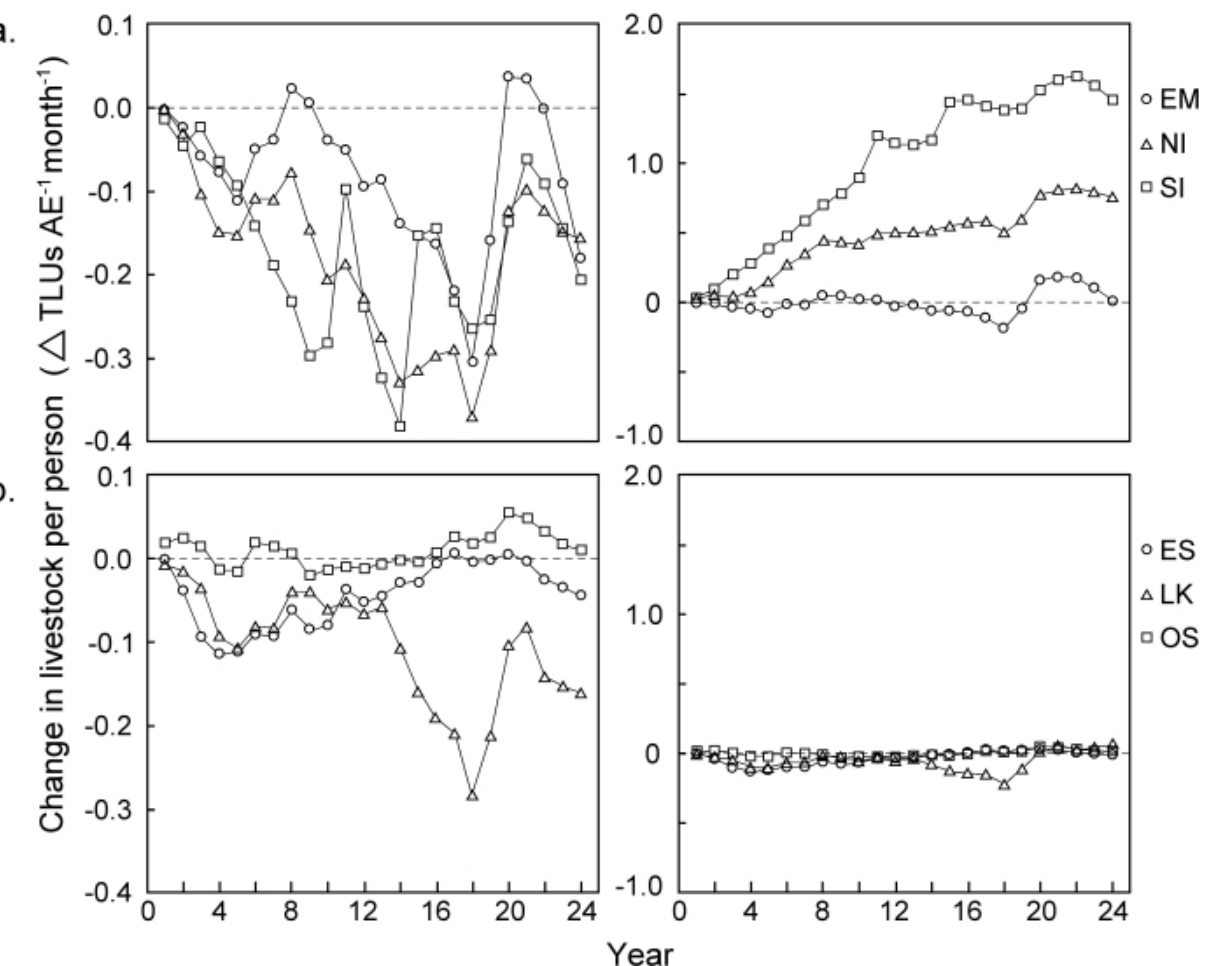

throughout simulations. Changes in livestock were less dramatic and more locally variable in these analyses than in the parallel analyses of Thornton et al. (2006). In that work, livestock were modeled as populations, and each month livestock were redistributed on the landscape. In resource poor months, many thousands of animals would be placed in the Chyulu Hills, and then placed a hundred kilometers away the following month. Livestock thereby made ready use of the grazing reserve without travel costs. In the agent-based approach, livestock were associated with specific places on the landscape. During typical dry seasons, households far from the Chyulu Hills did not travel to them, as in reality (BurnSilver 2007), and so those livestock were only affected by the change in access through interactions with animals from areas closer to the Chyulu Hills.

Subdividing a portion of the Chyulus for use by sedentarized Maasai for rain-fed agriculture has been discussed by community members, and simulated (Boone et al. 2006). A borehole pipeline has been constructed into the core of the grazing area, which if managed poorly would allow overgrazing in the reserve, as simulated in Galvin et al. (2008). Collectively, our results emphasize the importance of maintaining access to the Chyulu Hills for Maasai pastoralists. Novel results emerge here, given the place-based nature of the agentbased approach. The loss of access to the grazing reserve caused households closest to the Chyulus to lose livestock, but households more distant from the Chyulus gained livestock, because there are fewer livestock immigrating during the dry season and their herds had more forage per animal. The opposite response did not occur when people near the Chyulus were compensated for their loss of access. Household heads purchased more livestock, but they still had to support those animals near their permanent households in the wet season, and the number that could survive was limited. That number 
Table 2. Metrics that represent average (and standard error) responses across the six study areas for simulated households corresponding to the 184 for which survey data were available. Values given are: the base simulation (Base), when access to the Chyulu Hills was lost without compensation (No access), and when access was lost but households in ranches neighboring the Chyulu Hills were compensated (Leased).

\begin{tabular}{|c|c|c|c|c|c|c|c|}
\hline & & Osilalei & Eselenkei & Linkisim & Emeshenani & N. Imbirikani & S. Imbirikani \\
\hline Net income & Base & 1160 & 1749 & 1856 & 390 & 3196 & 1286 \\
\hline \multirow[t]{2}{*}{ (KSh/month) } & No access & $+2.6(61.1)$ & $+3.4(12.4)$ & $-67.7(18.7)^{* *}$ & +9.1(19.6) & $-61.6(37.1)^{* *}$ & $-24.6(42.5)$ \\
\hline & Leased & $-0.4(61.4)$ & $9.6(12.6)^{*}$ & $-72.4(18.9)^{* *}$ & $9.7(20.1)$ & $2166.2(36.1)^{* *}$ & $1880(48.7)^{* *}$ \\
\hline Cattle & Base & 755 & 1297 & 2516 & 6777 & 1635 & 934 \\
\hline \multirow[t]{2}{*}{ (total number) } & No access & $3(19)$ & $-110(29)^{* *}$ & $-410(76)^{* *}$ & $-309(184)$ & $-420(46)^{* * *}$ & $-97(23)^{* *}$ \\
\hline & Leased & $-30(20)$ & $-102(30)^{* * *}$ & $-163(96)$ & $65(149)$ & $818(89)^{* *}$ & $1339(64)^{* *}$ \\
\hline Goats & Base & 534 & 835 & 501 & 1110 & 3617 & 1467 \\
\hline \multirow[t]{2}{*}{ (total number) } & No access & $7(24)$ & $-101(36)^{*}$ & $7(12)$ & $-357(86)^{* *}$ & $-1002(182)^{* *}$ & $-381(114)$ \\
\hline & Leased & $5(26)$ & $-27(49)$ & $17(12)$ & $-224(90)$ & 341 (179) & $1570(170)^{* *}$ \\
\hline Sheep & Base & 499 & 988 & 454 & 1186 & 3815 & 1462 \\
\hline \multirow[t]{2}{*}{ (total number) } & No access & $12(10)$ & $93(33)^{*}$ & $1(7)$ & $-59(36)$ & $-181(95)$ & $-112(40)^{*}$ \\
\hline & Leased & $14(10)$ & $97(34)^{*}$ & $6(6)$ & $-23(33)$ & $939(126)^{* * *}$ & $1541(73)^{* *}$ \\
\hline Cattle sold & Base & 3.13 & 2.63 & 4.13 & 5.43 & 2.90 & 6.43 \\
\hline \multirow[t]{2}{*}{ (total/month) } & No access & $0.02(0.26)$ & $-0.04(0.20)$ & $0.14(0.26)^{* *}$ & $-0.40(0.33)^{* *}$ & $0.28(0.22)^{* *}$ & $0(0.34)$ \\
\hline & Leased & $0.04(0.26)$ & $-0.04(0.20)$ & $0.12(0.26)^{*}$ & $-0.48(0.32)^{* *}$ & $-1.67(0.09)^{* *}$ & $-4.11(0.20)^{* *}$ \\
\hline Cattle bought & Base & 3.23 & 7.21 & 5.60 & 1.01 & 11.88 & 6.78 \\
\hline \multirow[t]{2}{*}{ (total/month) } & No access & $0.04(0.14)$ & $0.03(0.25)$ & $-0.14(0.21)^{* *}$ & $0.00(0.01)$ & $-0.20(0.31)^{* *}$ & $-0.23(0.26)^{* *}$ \\
\hline & Leased & $0.04(0.14)$ & $0.02(0.24)$ & $-0.18(0.21)^{* *}$ & $0.00(0.01)$ & $7.85(0.32)^{* *}$ & $8.75(0.38)^{* *}$ \\
\hline Cattle gifted & Base & 8.17 & 18.91 & 20.60 & 10.58 & 9.89 & 9.83 \\
\hline \multirow[t]{2}{*}{ (total/month) } & No access & $-0.02(1.78)$ & $0.76(2.40)^{* *}$ & $-1.55(3.27)$ & $3.13(3.71)^{* *}$ & $-0.59(1.47)$ & $-0.76(1.36)^{* *}$ \\
\hline & Leased & $-0.20(1.76)$ & $0.52(2.30)$ & $-4.92(2.73)^{* *}$ & $-0.02(2.22)$ & $-3.83(1.62)^{* *}$ & $-0.12(1.86)$ \\
\hline Milk energy consumed & Base & 15763 & 24212 & 27850 & 30009 & 26233 & 17142 \\
\hline (kCal/month) & No access & $90(329)$ & $135(330)$ & $-752(296)^{*}$ & $2224(389)^{* *}$ & $-3205(534)^{* *}$ & $-888(340)^{*}$ \\
\hline
\end{tabular}




\begin{tabular}{|c|c|c|c|c|c|c|c|}
\hline & Leased & $-189(380)$ & $721(290)^{*}$ & $-310(342)$ & $2184(416)^{* *}$ & $2458(506)^{* *}$ & $5851(332)^{* * *}$ \\
\hline Meat energy consumed & Base & 3144 & 5657 & 6232 & 7386 & 11082 & 5042 \\
\hline \multirow[t]{2}{*}{ (kCal/month) } & No access & $57(142)$ & $-38(173)$ & $-458(167)^{* *}$ & $756(224)^{* *}$ & $-993(230)^{* *}$ & $-348(169)^{*}$ \\
\hline & Leased & $-24(145)$ & $100(176)$ & $-256(169)^{* *}$ & $913(221)^{* *}$ & $1211(142)^{* *}$ & $3078(142)^{* *}$ \\
\hline $\begin{array}{l}\text { Plant energy } \\
\text { consumed }\end{array}$ & Base & 0 & 0 & 388 & 336 & 5937 & 8478 \\
\hline \multirow[t]{2}{*}{ (kCal/month) } & No access & $0(0)$ & $0(0)$ & $-1.8(8.0)$ & $-2.0(6.3)$ & $-40.8(200.5)$ & $-79.1(261.5)$ \\
\hline & Leased & $0(0)$ & $0(0)$ & $-1.8(8.0)$ & $-2.0(6.3)$ & $-48.0(183.7)$ & $-88.2(239.2)^{*}$ \\
\hline $\begin{array}{l}\text { Bought energy } \\
\text { consumed }\end{array}$ & Base & 47981 & 59939 & 63963 & 65910 & 64832 & 56446 \\
\hline \multirow[t]{2}{*}{ (kCal/month) } & No access & $565(742)^{*}$ & $509(677)^{*}$ & $531(759)$ & $-531(800)$ & $3199(708)^{* *}$ & $1461(996)^{* *}$ \\
\hline & Leased & $663(728)^{* *}$ & $120(657)$ & $212(746)$ & $-829(777)^{* *}$ & $-2238(639)^{* *}$ & $585(793)$ \\
\hline $\begin{array}{l}\text { Gifted energy } \\
\text { consumed }\end{array}$ & Base & 12728 & 11273 & 9468 & 11814 & 2679 & 12082 \\
\hline \multirow[t]{2}{*}{ (kCal/month) } & No access & $-858(567)^{* * *}$ & $-618(640)$ & $680(679)^{*}$ & $-2435(652)^{* *}$ & $1029(208)^{* *}$ & $-148(744)$ \\
\hline & Leased & $-599(563)$ & $-963(610)^{*}$ & 355 (669) & $-2258(648)^{* *}$ & $-1347(12)^{* *}$ & $-9093(364)^{* * *}$ \\
\hline Milk energy sold $^{\dagger}$ & Base & 123 & 133 & 1500 & 199 & 617 & 960 \\
\hline \multirow[t]{2}{*}{ (kCal/month) } & No access & $-14(11)$ & $-5(6)^{*}$ & $-768(101)^{* *}$ & $50(15)^{* *}$ & $-132(44)^{* *}$ & $-38(42)$ \\
\hline & Leased & $-27(12)$ & $-5(6)^{* *}$ & $-873(107)^{* *}$ & $31(15)^{*}$ & $200(63)^{* *}$ & $1561(115)^{* * *}$ \\
\hline Plant energy sold ${ }^{\dagger}$ & Base & 337.6 & 1.0 & 233.2 & 202.4 & 3517.3 & 5089.4 \\
\hline \multirow[t]{2}{*}{ (kCal/month) } & No access & $61.2(123.5)^{*}$ & $0.1(0.4)$ & $-1.0(5.2)$ & $-1.2(4.8)$ & $-25.7(97.3)$ & $-52.0(137.6)$ \\
\hline & Leased & $61.2(123.5)^{*}$ & $0.1(0.4)$ & $-1 . .0(5.2)$ & $-1.2(4.8)$ & $-25.7(97.3)$ & $-52.0(137.6)$ \\
\hline Animal energy sold & Base & 1379 & 1421 & 2164 & 3394 & 1326 & 2762 \\
\hline \multirow[t]{2}{*}{ (kCal/month) } & No access & $-74(120)^{* *}$ & $28(107)^{* *}$ & $-6(125)$ & $108(204)^{* *}$ & $-3(92)$ & $16(149)$ \\
\hline & Leased & $-71(120)^{* *}$ & $39(110)^{* *}$ & $10(126)$ & $122(205)^{* *}$ & $-912(41)^{* *}$ & $-1593(92)^{* *}$ \\
\hline
\end{tabular}

${ }^{*} \mathrm{P} \leq 0.05$ when compared to no change from the baseline model (one sample t-test with Bonferroni adjustment).

${ }^{* *} \mathrm{P} \leq 0.005$ when compared to no change from the baseline model (one sample t-test with Bonferroni adjustment).

${ }^{\dagger}$ Plant energy is consumed, and milk and plant energy sold, in three or fewer months per year, yielding low mean values. 
was insufficient to cause households more distant from the Chyulus to lose animals due to the increased competition for forage.

Two effects contribute to trends in responses in our baseline model (Fig. 4). First, Kajiado pastoralists return their herds to their permanent homes during the wet season (BurnSilver 2007), but in the simulation some permanent households occupy areas that cannot provide sufficient forage. Households in these locations may lose animals in most years, and be restocked through gifts. Second, families with members earning salaries may purchase many animals. Some families lose animals and other families purchase animals, but overall the total livestock numbers remain stable over the long term. However, poor households far outnumber wealthy households and so the median household response was a gradual decline in livestock numbers. Indeed, the portion of households owning half the livestock was $12.5 \%$ in surveys and $8 \%$ in the base simulation.

The ability to summarize responses at individualto-population scales leads to a main challenge of our approach. In the PHEWS model, the numbers of control parameters and output categories were similar. In general, controls could be adjusted to alter responses more-or-less directly. In agentbased DECUMA, the number of control parameters is far less than the responses. For example, here about 11460 herds were being simulated. The same types of adjustments to parameters are made in DECUMA as in PHEWS. But upon summation of the results, if some households are selling far more than they should and some selling far less, that cannot be adjusted directly. Instead, one must consider why the differences may be occurring and make adjustments through a synthetic systems approach. This way of modeling is appropriate, but the process of parameterizing the coupled simulations can be iterative and complex.

Our simulations are not intended to represent conditions 24 years into the future. Too many changes to the linked systems will occur in that time to make such predictions possible. However, our results do quantify household well-being over time if a single change in access occurs, for example. Moreover, the caveats associated with SAVANNA modeling apply here as well (see Boone et al. 2005, Boone 2007).

With DECUMA linked with the SAVANNA model, changes in ecosystem services influenced the decisions made by household members, which in turn influenced ecosystem services. Linking complex models brings challenges, but this approach increases the potential for emergent responses and secondary interactions to be considered. Using DECUMA, responses may be summarized at different scales, attributes of individual households are known and can change over a simulation, and pastoralists have permanent household locations and temporary camps with environments that influence their decision making.

Responses to this article can be read online at:

http://www.ecologyandsociety.org/voll6/iss2/art6/responses/

\section{Acknowledgments:}

We thank three anonymous reviewers and the Subject Editor for providing comments that helped us to improve the manuscript. Our study of resiliency in livestock-owning households and the development of DECUMA is supported by the National Science Foundation, grant SES-0527481 to Galvin et al., with additional support from grants BCS-0822752 and BCS-0624315.

\section{LITERATURE CITED}

Behnke, R. H., I. Scoones, and C. Kervin. 1993. Range ecology at disequilibrium: new models of natural variability and pastoral adaptations in African savannas. Overseas Development Institute, London, UK.

Bonabeau, E. 2002. Agent-based modeling: methods and techniques for simulating human systems. Proceedings of the National Academy of Science USA 99:7280-7287.

Boone, R. B. 2005. Quantifying changes in vegetation in shrinking grazing areas in Africa. Conservation and Society 3:150-173.

Boone, R. B. 2007. Effects of fragmentation on cattle in African savannas under variable precipitation. Landscape Ecology 22:1355-1369.

Boone, R. B., S. B. BurnSilver, and P. K. Thornton. 2006. Optimizing aspects of land use intensification in southern Kajiado District, Kenya. Report to the 
International Livestock Research Institute, Nairobi, Kenya. [online] URL: http://warnercnr.colostate.edu/ rboone/pubs/Boone et al Reto Final Dec 2006.pdf.

Boone, R. B., S. B. BurnSilver, P. K. Thornton, J. S. Worden, and K. A. Galvin. 2005. Quantifying declines in livestock due to land subdivision in Kajiado District, Kenya. Rangeland Ecology \& Management 58:523-532.

Boone, R. B., K. A. Galvin, P. K. Thornton, D. M. Swift, and M. B. Coughenour. 2006. Cultivation and conservation in Ngorongoro Conservation Area, Tanzania. Human Ecology 34:809-828.

Boone, R. B., and G. Wang. 2007. Cattle dynamics in African grazing systems under variable climate. Journal of Arid Environments 70:495-413.

Braun, H. M. H. 1980. Exploratory soil map and agro-climatic soil map of Kenya. Ministry of Agriculture, Nairobi, Kenya.

Brody, S. 1945. Bioenergetics and growth. Reinhold, New York, New York, USA.

Browne-Nuñez, C., and S. A. Jonker. 2008. Attitudes toward wildlife and conservation across Africa: a review of survey research. Human Dimensions of Wildlife 13:47-70.

Bulte, E. H., R. B. Boone, R. Stringer, and P. K. Thornton. 2008. Elephants or onions? Paying for nature in Amboseli, Kenya. Environment and Development Economics 13:395-414.

BurnSilver, S. B. 2007. Pathways of continuity and change: diversification, intensification and mobility in Maasailand, Kenya. Thesis (Ph.D.). Graduate Degree Program in Ecology, Colorado State University, Fort Collins, Colorado, USA.

Castella, J.-C., T. N. Trung, and S. Boissau. 2005. Participatory simulation of land-use changes in the northern mountains of Vietnam: the combined use of an agent-based model, a role-playing game, and a geographic information system. Ecology and Society 10:27. [online] URL: http://www.ecologya ndsociety.org/articles/1328.html.

Christensen, L., M. B. Coughenour, J. E. Ellis, and Z. Chen. 2004. Sustainability of the Asian grasslands: application of the SAVANNA model. Journal of Range Management 56:319-327.
Cioffi-Revilla, C., J. D. Rogers, and M. M. Latek. 2008. The MASON HouseholdsWorld model of pastoral nomad societies. Pages 193-201 in K. Takadama, G. Deffuant, and C. Cioffi-Revilla, editors. Simulationg interacting agents and social phenomena, the second world congress. Postproceedings of the Second World Congress on Social Simulation, George Mason University, Fairfax, Virginia, USA, July 14-17, 2008. Springer.

Coughenour, M. B. 1985. Graminoid response to grazing by large herbivores: adaptations, exaptations, and interacting processes. Annals of the Missouri Botanical Garden 72:852-863.

Coughenour, M. B. 1992. Spatial modelling and landscape characterization of an African pastoral ecosystem: a prototype model and its potential use for monitoring drought. Pages 787-810 in D. H. McKenzie, D. E. Hyatt, and V. J. McDonald, editors. Ecological indicators. Elsevier Applied Science, New York, New York, USA.

Coughenour, M. B., and F. J. Singer. 1996. Yellowstone elk population responses to fire-a comparison of landscape carrying capacity and spatial-dynamic ecosystem modeling approaches. Pages 169-180 in J. Greenlee, editor. The ecological implications of fire in greater Yellowstone. International Association of Wildland Fire, Fairfield, Washington, USA.

Daily, G. C. 2000. Management objectives for the protection of ecosystem services. Environmental Science \& Policy 3:333-339.

Daily, G. C., and P. A. Matson. 2008. Ecosystem services: from theory to implementation. Proceedings of the National Academy of Science USA 105:9455-9456.

Eastman, J. L., M. B. Coughenour, and R. A. Pielke, Sr. 2001. The regional effects of $\mathrm{CO}_{2}$ and landscape change using a coupled plant and meteorological model. Global Change Biology 7:797-815.

Ellis, J., and M. B. Coughenour. 1998. The SAVANNA integrated modeling system. Pages 97-106 in V. Squires, and A. Sidahmed, editors. Drylands: sustainable use of rangelands in the twenty-first century. International Fund for Agricultural Development (IFAD) Technical Reports, Rome, Italy. 
Epstein, J. M. 1999. Agent-based computational models and generative social science. Complexity 4:41-60.

Evans, T. P., and H. Kelley. 2004. Multi-scale analysis of a household level agent-based model of landcover change. Journal of Environmental Management 72:57-72.

Evans, T. P., and S. Manson. 2007. Space, complexity, and agent-based modeling. Environmental Planning B: Planning and Design 34:196-199.

Food and Agriculture Organization of the United Nations (FAO). 2001. Pastoralism in the new millennium. FAO Animal Production and Health Paper 150, Rome, Italy.

Fratkin, E., and K. Smith. 2005. Women's changing economic roles with pastoral sedentarization: varying strategies in alternate Rendille communities. Pages 433-454 in E. Fratkin and E. A. Roth, editors. As pastoralists settle: social, health, and economic consequences of pastoral sedentarization in Marsabit District, Kenya. Studies in Human Ecology and Adaptation, Vol. 1, Springer, New York, New York, USA.

Galvin, K. A., R. B. Boone, S. B. BurnSilver, and P. K. Thornton. 2008. Humans and wildlife as ecosystem components in integrated assessments. Pages 129-142 in M. J. Manfredo, J. J . Vaske, P. J. Brown, and D. J. Decker, editors. Wildlife and society in the twenty-first century. Island Press, Washington, D.C., USA.

Galvin, K. A., P. K. Thornton, R. B. Boone, and J. Sunderland. 2004. Climate variability and impacts on East African livestock herders: the Maasai of Ngorongoro Conservation Area, Tanzania. African Journal of Range and Forage Science 21:183-189.

Galvin, K. A., P. K. Thornton, J. R. de Pinho, J. Sunderland, and R. B. Boone. 2006. Integrated modeling and its potential for resolving conflicts between conservation and people in the rangelands of East Africa. Human Ecology 34:155-183.

Government of Kenya. 2003. Geographic dimensions of well-being in Kenya. Vol. 1: Where are the poor? From districts to locations. Ministry of Planning and National Development, Central Bureau of Statistics, Nairobi, Kenya.
Grimm, V., U. Berger, F. Bastiansen, S. Eliassen, V. Ginot, J. Giske, J. Goss-Custard, T. Grand, S .K. Heinz, G. Huse, A. Huth, J. U. Jepsen, C. Jørgensen, W. M. Mooij, B. Müller, G. Pe'er, C. Piou, S. F. Railsback, A. M. Robbins, M. M. Robbins, E. Rossmanith, N. Rüger, E. Strand, S. Souissi, R. A. Stillman, R. Vabø, U. Visser, and D.L. DeAngelis. 2006. A standard protocol for describing individualbased and agent-based models. Ecological Modelling 198:115-126.

Grimm, V., E. Revilla, U. Berger, F. Jeltsch, W. M. Mooij, S. F. Railsback, H.-H. Thulke, J. Weiner, T. Wiegand, and D. L. DeAngelis. 2005. Patternoriented modeling of agent-based complex systems: lessons from ecology. Science 310:987-991.

Gross, J. E., R. R. J. McAllister, N. Abel, D. M. Stafford Smith, and Y. Maru. 2006. Australian rangelands as complex adaptive systems: a conceptual model and preliminary results. Environmental Modelling Software 21:1264-1272.

Huysentruyt, M., C. B. Barrett, and J. G. McPeak. 2009. Understanding declining mobility and interhousehold transfers among East African pastoralists. Economica 76:315-336.

Intergovernmental Panel on Climate Change (IPCC). 2007. Climate change 2007: the physical science basis, summary for policymakers. World Meteorological Organization and the United Nations Environment Programme, Geneva, Switzerland.

Janssen, M. A., and E. Ostrom. 2006. Empirically based, agent-based models. Ecology and Society 11:37. [online] URL: http://www.ecologyandsociety. org/vol11/iss2/art37.

Kuznar, L. A., and R. Sedlmeyer. 2005. Collective violence in Darfur: an agent-based model of pastoral nomad/sedentary peasant interactions. Mathematical Anthropology and Cultural Theory 1:1-22.

Leslie, P. H. 1945. On the use of matrices in certain population mathematics. Biometrika 33:183-212.

Leslie, P. H. 1948. Some further notes on the use of matrices in population mathematics. Biometrika 35:213-245.

Milner-Gulland, E. J., C. Kerven, R. Behnke, I. A. Wright, and A. Smailov. 2006. A multi-agent 
system model of pastoralist behaviour in Kazakhstan. Ecological Complexity 3:23-36.

Ole Katampoi, K., G. Genga, M. Mwangi, J. Kipkan, J. Ole Seitah, M. K. van Klinken, and M. S. Mwangi. 1990. Kajiado District atlas. ASAL Programme Kajiado and the Ministry of Reclamation and Development of Arid, Semi-Arid Areas and Wastelands, Kajiado, Kenya.

Parker, D. C., S. M. Manson, M. A. Janssen, M. J. Hoffman, and P. Deadman. 2003. Multi-agent systems for the simulation of land-use and landcover change: a review. Annals of the Association of American Geographers 93:314-337.

Peck, S. L. 2004. Simulation as experiment: a philosophical reassessment for biological modeling. Trends in Ecology and Evolution 19:530-534.

Polhill, J. G., D. Parker, D. Brown, and V. Grimm. 2008. Using the ODD protocol for describing three agent-based simulation models of land-use change. Journal of Artificial Societies and Social Simulation 11(2):3. [online] URL: http://jasss.soc.surrey.ac.uk /11/2/3.html.

Rutten, M. M. E. M. 1992. Selling wealth to buy poverty: the process of the individualization of land ownership among the Maasai pastoralists of Kajiado District, Kenya, 1890-1990. Verlag breitenbach, Saarbrücken, Germany.

Rykiel, E. J. 1996. Testing ecological models: the meaning of validation. Ecological Modelling 90:229-244.

Thompson, M., and K. Homewood. 2002. Entrepreneurs, elites, and exclusion in Maasailand: trends in wildlife conservation and pastoralist development. Human Ecology 30:107-138.

Thornton, P. K., S. B. BurnSilver, R. B. Boone, and K. A. Galvin. 2006. Modelling the impacts of group ranch subdivision on agro-pastoral households in Kajiado, Kenya. Agricultural Systems 87:331-356.

Thornton, P. K., K. A. Galvin, and R. B. Boone. 2003. An agro-pastoral household model for the rangelands of East Africa. Agricultural Systems 76:601-622.

Van Horne, B., and J. A. Wiens. 1991. Forest bird habitat suitability models and the development of general habitat models. Fish and Wildlife Research 8, U.S. Department of the Interior Fish and Wildlife Service, Washington, D.C., USA.

Worden, J. S. 2007. Fragmentation and settlement pattern in Maasailand: implications for pastoral mobility, drought vulnerability, and wildlife conservation in an east African savanna. Thesis ( $\mathrm{Ph}$. D.). Graduate Degree Program in Ecology, Colorado State University, Fort Collins, Colorado, USA. 
APPENDIX 1. An example household characterization file, used as input into the DECUMA model. AE is adult equivalents, used to standardize humans of different age and sex into a single metric. Ksh is Kenyan shillings.

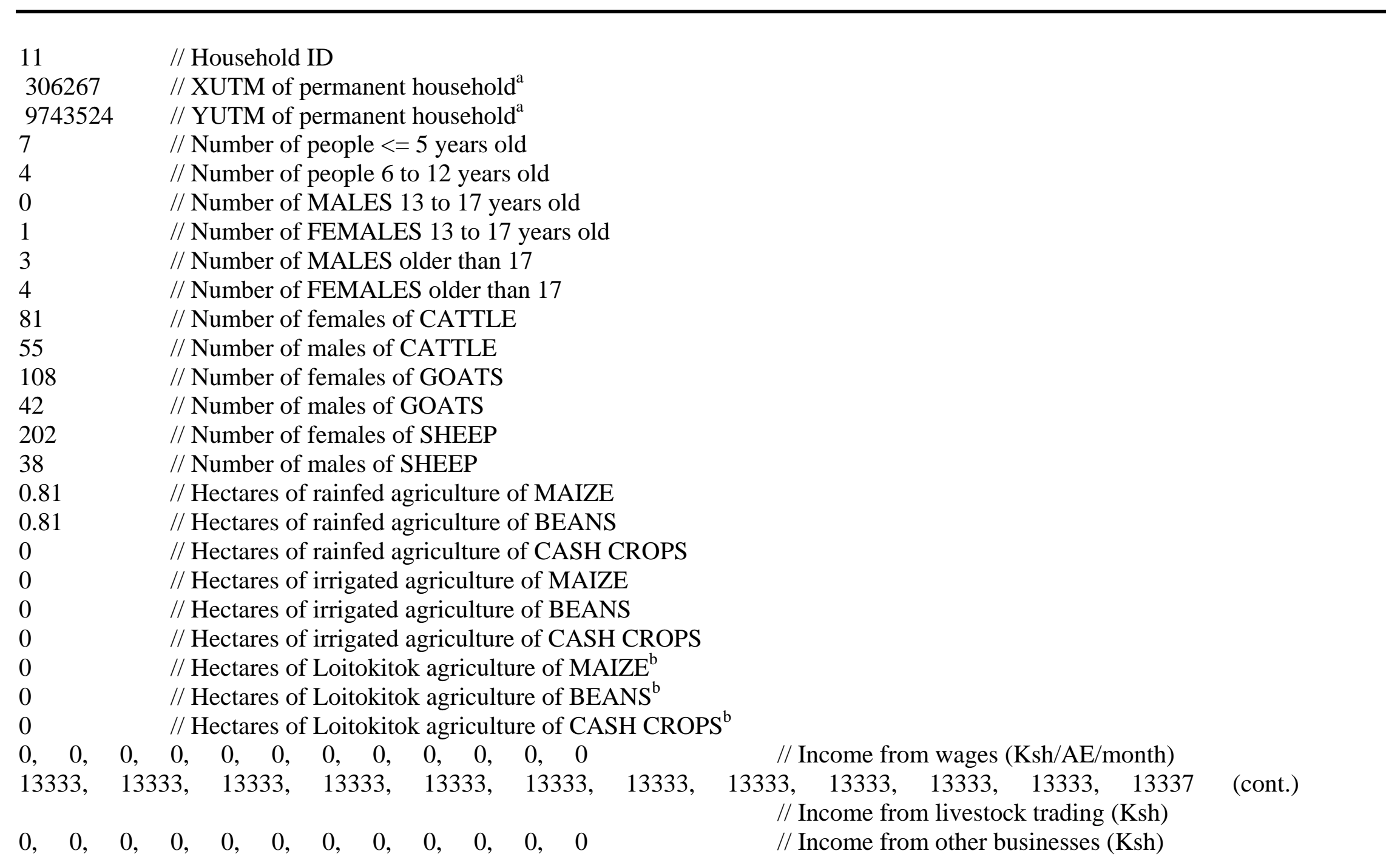


506, 506, 506, 506, 506, 506, 506, 506, 506, 506, 506, 512

// Expenses, food, tea and sugar (Ksh/AE/month)

716, 50, 50, 716, 50, 50, 50, 50, 50, 718, 50, $56 \quad$ // Expenses, general expenses, school fees (Ksh/month)

650, 650, 650, 650, 650, 650, 650，650，650，650，650，650 // Expenses, crop inputs (Ksh/month)

1541, 1541, 1541, 1541, 1541, 1541, 1541, 1541, 1541, 1541, 1541, 1544

// Expenses, veterinary inputs (Ksh/month)

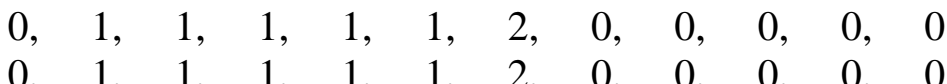

$1, \quad 1, \quad 1, \quad 1, \quad 1, \quad 2, \quad 1, \quad 1, \quad 1, \quad 1, \quad 1, \quad 2$

// Maize harvest flag, $1=$ PPT counts, $2=$ Harvest $^{\mathrm{d}}$

// Beans harvest flag, $1=$ PPT counts, $2=$ Harvest $^{\mathrm{d}}$

0.0050, $0.0050, \quad 0.0050, \quad 0.0050, \quad 0.0050, \quad 0.0050, \quad 0.0050, \quad 0.0050, \quad 0.0050, \quad 0.0050, \quad 0.0050, \quad 0.0050 \quad$ (cont.)

// Other harvest flag, $1=$ PPT counts, $2=$ Harvest $^{\mathrm{d}}$

$\begin{array}{ll}0 & \text { // Initial monetary holdings }(\mathrm{Ksh})^{\mathrm{c}} \\ 0 & \text { // Initial debt }(\mathrm{Ksh})^{\mathrm{c}} \\ 0 & \text { // Initial assets }(\mathrm{Ksh})^{\mathrm{c}} \\ 38 & \text { // Initial age of household head } \\ 2 & \text { // Regional area }\end{array}$

// Probability of opportunistic slaughter

a - UTM coordinates were altered to disguise household identity.

b - Loitokitok cultivation is rainfed, but in the higher rainfall areas on the slopes of Mount Kilimanjaro.

c - These parameters are placeholders for future applications. They were either unavailable or zero for all households in the current application.

$\mathrm{d}$ - Flags may be 2, meaning the crop is harvested that month, 0 , with no effect, or 1 , which indicates that precipitation in that month should be used in calculating the total yield from the plot.

e - One of seven regions into which the study area was divided. 
APPENDIX 2. The primary parameter file that provides metrics used in the DECUMA file that are common across all households. $\mathrm{AE}$ is adult equivalents, used to standardize humans of different age and sex into a single metric. Ksh is Kenyan shillings.

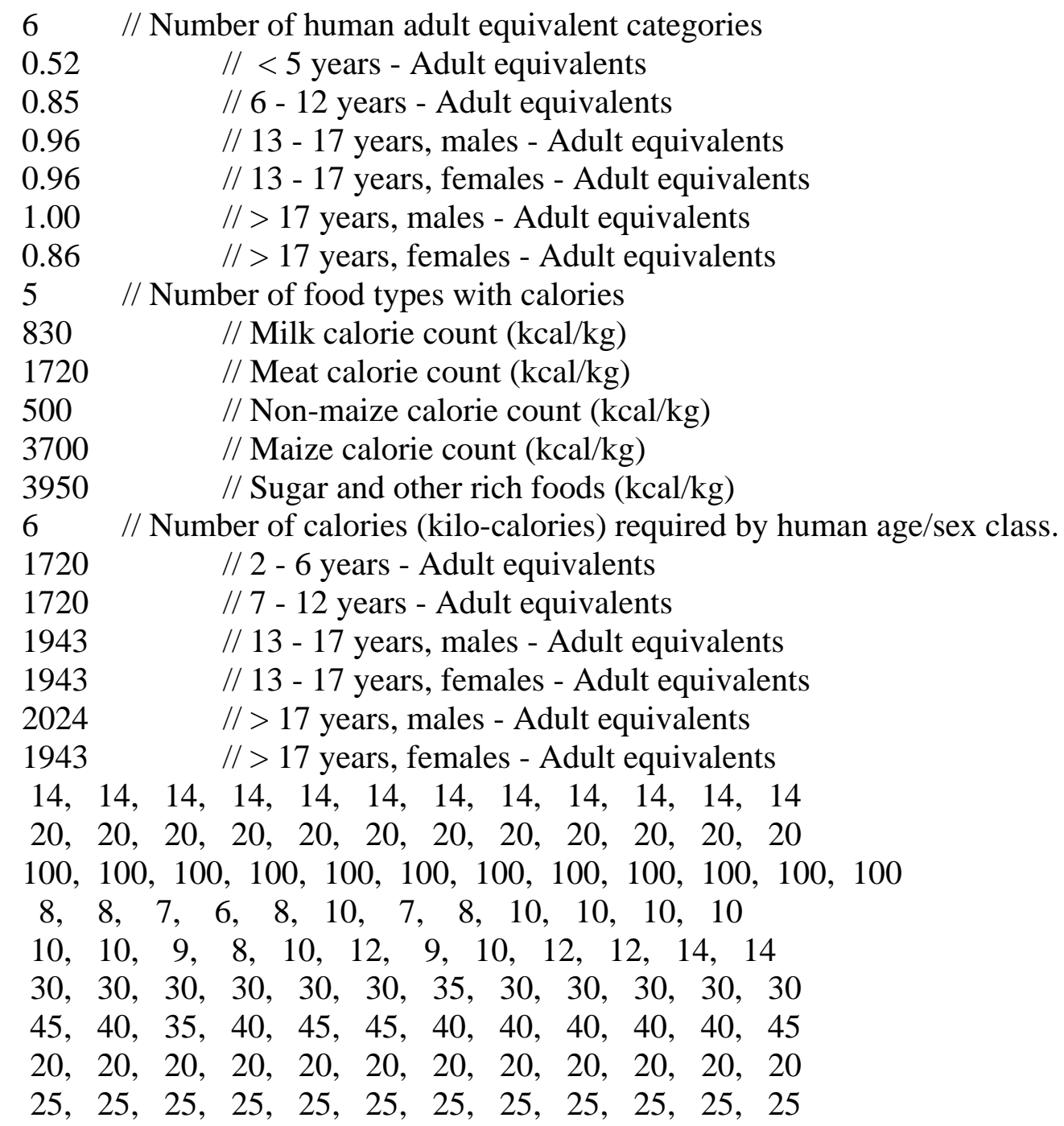

\author{
// Milk price sell KSh/kg by month \\ // Milk price buy KSh/kg by month \\ // Tea/sugar cost KSh/kg by month \\ // Maize price sell KSh/kg by month \\ // Maize price buy KSh/kg by month \\ // Beans price sell KSh/kg by month \\ // Beans price buy $\mathrm{KSh} / \mathrm{kg}$ by month \\ // Toms price sell KSh/kg by month \\ // Tomatoes price buy KSh/kg by month
}


$20,20,20,20,20,20,20,20,20,20,20,20$

$30,30,30,30,30,30,30,30,30,30,30,30$

$1500,1500,1500,1500,1500,1500,1500,1500,1500,1500,1500,1500$

$3000,3000,3000,3000,3000,3000,3000,3000,3000,3000,3000,3000$

$3000,3000,3000,3000,3000,3000,3000,3000,3000,3000,3000,3000$

$10000,10000,10000,10000,10000,10000,10000,10000,10000,10000,10000,10000 / /$

$11000,11000,11000,11000,11000,11000,11000,11000,11000,11000,11000,11000 / /$

$2000,2000,2000,2000,2000,2000,2000,2000,2000,2000,2000,2000$

$4000,4000,4000,4000,4000,4000,4000,4000,4000,4000,4000,4000$

$4000,4000,4000,4000,4000,4000,4000,4000,4000,4000,4000,4000$

$12000,12000,12000,12000,12000,12000,12000,12000,12000,12000,12000,12000 / /$

$14000,14000,14000,14000,14000,14000,14000,14000,14000,14000,14000,14000 / /$

$400,400,400,400,400,400,400,400,400,400,400,400$

$700,700,700,700,700,700,700,700,700,700,700,700$

$700,700,700,700,700,700,700,700,700,700,700,700$

$1500,1500,1500,1500,1500,1500,1500,1500,1500,1500,1500,1500$

$1500,1500,1500,1500,1500,1500,1500,1500,1500,1500,1500,1500$

$600,600,600,600,600,600,600,600,600,600,600,600$

$1000,1000,1000,1000,1000,1000,1000,1000,1000,1000,1000,1000$

$1000,1000,1000,1000,1000,1000,1000,1000,1000,1000,1000,1000$

2000, 2000, 2000, 2000, 2000, 2000, 2000, 2000, 2000, 2000, 2000, 2000

2000, 2000, 2000, 2000, 2000, 2000, 2000, 2000, 2000, 2000, 2000, 2000

$400,400,400,400,400,400,400,400,400,400,400,400$

$700,700,700,700,700,700,700,700,700,700,700,700$

$700,700,700,700,700,700,700,700,700,700,700,700$

$1500,1500,1500,1500,1500,1500,1500,1500,1500,1500,1500,1500$

$1500,1500,1500,1500,1500,1500,1500,1500,1500,1500,1500,1500$

$600,600,600,600,600,600,600,600,600,600,600,600$

$1000,1000,1000,1000,1000,1000,1000,1000,1000,1000,1000,1000$

$1000,1000,1000,1000,1000,1000,1000,1000,1000,1000,1000,1000$

2000, 2000, 2000, 2000, 2000, 2000, 2000, 2000, 2000, 2000, 2000, 2000

2000, 2000, 2000, 2000, 2000, 2000, 2000, 2000, 2000, 2000, 2000, 2000

$0.0,0.2,0.5,1.0$
// Onion price sell $\mathrm{KSh} / \mathrm{kg}$ by month

// Onion price buy $\mathrm{KSh} / \mathrm{kg}$ by month

// Cattle 1 sell KSh by month ${ }^{\mathrm{a}}$

// $\quad 2$ sell KSh by month

// 3 sell KSh by month

4 sell KSh by month

5 sell KSh by month

Cattle 1 buy KSh by month

2 buy KSh by month

3 buy KSh by month

4 buy KSh by month

5 buy KSh by month

Goats 1 sell KSh by month

2 sell KSh by month

3 sell KSh by month

4 sell KSh by month

5 sell KSh by month

Goats 1 buy KSh by month

2 buy KSh by month

3 buy KSh by month

4 buy KSh by month

5 buy KSh by month

Sheep 1 sell KSh by month

2 sell KSh by month

3 sell KSh by month

4 sell KSh by month

5 sell KSh by month

Sheep 1 buy KSh by month

2 buy KSh by month

3 buy KSh by month

4 buy KSh by month

5 buy KSh by month 
17.80, 42.40, 42.40, 74.2, 95.9

$3.97,6.36,6.36,10.6,12.3$

$3.97,6.36,6.36,10.6,12.3$

0.05

0.05

0.05

$0.0,0.5, \quad 1.0,1.0$

$150.0,0.0,600.0,0.8$

$150.0,0.0,800.0,0.4$

780, 1800, 20000

$14.0,20.0$

$0.0,8.0,500.0,75.0$

$0.0,1.5,1000.0,10.0$

$0.0,1.5,1000.0,10.0$

$1,2,2,3,3,2,1,1,1,1,3,2$

10.0

$0.0,0.0,0.2,0.9,0.9,0.2,0.0,0.0,0.0,0.0,0.8,0.1$

200., .2, 1500., 1.0

200., .2, 1500., 1.0

2., .2, 200., 1.0

2., .2, 200., 1.0

2., .2, 200., 1.0

2., .2, 200., 1.0

$0.45,1.00$

$0 ., 1.0,25 ., 1.0$

$0 ., 1.0,25 ., 0.9$

$0 ., 1.0,75 ., 0.1$

$0 ., 1.0,10 ., 0.1$

$0 ., 1.0,10 ., 0.1$

$2,2,2,2,2,2,2,1,1,1,2,2$

0.05
// Cattle Max kg meat by class

// Goat Max kg meat by class

// Sheep Max kg meat by class

// Cattle Prop non-edible deaths

// Goat Prop non-edible deaths

// Sheep Prop non-edible deaths

// Meat yield vs condition ${ }^{c}$

// Maize yield vs precipitation $\mathrm{mm}^{\mathrm{d}}$

// Bean yield vs precipitation $\mathrm{mm}^{\mathrm{d}}$

// Triggers to sell small stock, Trigger to sell larger stock ${ }^{\mathrm{e}}$

// Trigger multipliers to spur smallstock and largestock livestock (cont.) purchase. If cash need is much smaller than assets, buy an animal ${ }^{\mathrm{f}}$

// Cattle density (per $\mathrm{km}^{2}$ ) of livestock TLUs ${ }^{\mathrm{g}}$

// Goat density (per km²) of livestock TLUs ${ }^{\mathrm{g}}$

// Sheep density (per $\mathrm{km}^{2}$ ) of livestock TLUs ${ }^{\mathrm{g}}$

// Rainfall maps to use, by month (1=Dry, 2=Transition, 3=Wet)

// Grazing orbit, in $\mathrm{km}^{\mathrm{h}}$

// Likelihood herders will return to their permanent home ${ }^{\mathrm{i}}$

// Cattle short-term HSI density versus Suitability Index

// Cattle long-term HSI density versus Suitability Index

// Goat short-term HSI density versus Suitability Index

// Goat long-term HSI density versus Suitability Index

// Sheep short-term HSI density versus Suitability Index

// Sheep long-term HSI density versus Suitability Index

// Coefficient for outside the group ranch, and inside the group ranch

// Distance to permanent household $(\mathrm{km})$ versus Suitability Index

// Distance to current camp (km) versus Suitability Index

// Cattle density (TLUs per $\mathrm{km}^{2}$ ) versus Suitability Index

// Goat density (TLUs per $\mathrm{km}^{2}$ ) versus Suitability Index

// Sheep density (TLUs per $\mathrm{km}^{2}$ ) versus Suitability Index

// Integers showing which force map to use each month ${ }^{\mathrm{j}}$

// Desire to stay at their current location ${ }^{\mathrm{k}}$ 
a - Here and in many lines of this file, livestock age/sex classes are referred to, which are: 1 - calves of both sexes, 2 - young (nonbreeding) females, 3 - young males, 4 - adult females, and 5 - adult males.

$\mathrm{b}$ - A linear function relates animal condition indices from 0.0 to 1.0 to a multiplier on milk production, here from 0.2 to 1.0 .

c - A linear function relates animal condition indices from 0.0 to 1.0 to a multiplier on meat yield, here from 0.5 to 1.0 .

$\mathrm{d}$ - A linear function relates amount of precipitation during appropriate months to crop yields.

e - Triggers, in KSh, of money needed over the long-term, calculated each time step. If the need exceeds these triggers, small or large livestock are sold.

$\mathrm{f}$ - Triggers, in KSh, of cash holding that would trigger households to purchase livestock. If their holdings exceed these triggers, small or large livestock are purchased.

g - A linear function relates maximum densities of animals given habitat suitability values.

$\mathrm{i}$ - This measure, and those on the following 12 lines, are used in deciding when to move herds to a temporary camp location.

$\mathrm{j}$ - A flag indicating which force map to use. Force maps control the distribution of animals, in ways that are not associated with ecological relationships (e.g., limits in access due to fences or legal restrictions).

$\mathrm{k}$ - A measure used in deciding when to move herds to temporary camp locations. 
APPENDIX 3. The main controlling program of DECUMA, with each line of Fortran 95 code annotated.

\begin{tabular}{l}
\hline Code or Module Call \\
program Decuma \\
use Parameter_Values \\
implicit none \\
call Initialize_Values \\
call Initialize_Metrics \\
call Initialize_Landscapes \\
call Initialize_Livestock \\
call Initialize_Houses \\
call Initialize_Herds
\end{tabular}

if (statev_flag $==2$.or. statev_flag $==3$ ) then call Restore_HSID_Long_Term end if call Restore_Agents

call Livestock_Update_Summarize call Update_Agents

call Livestock_Distribute

do nmonth=1,months_modeled

call Monthly_Inputs

Write $(*, *)$ 'Year: ',year,' Month: ‘,month do week=1,4

call Livestock_Distribute

call Livestock_Energy_Acquired

call Livestock_Update_Summarize end do

call Livestock_Energy_Used

\section{Action or Activities}

Initialize the program DECUMA

Import into the program general parameter names (e.g., file names, constants)

Require all the parameters to be explicitly declared, to avoid typographic errors

Input parameter values that control program simulation (e.g., months modeled) Input parameter values that describe human energy needs, buy and sell prices, sheep forage units, human adult equivalents, and movement thresholds Read landscape maps (e.g., household density) into the internal spatial database Input values for initial livestock age distributions and energy requirement Initialize households, including their livestock holdings and all other attributes Distribute each household's livestock species into age and sex cohorts

If file from a spin-up is to be read-in (2) or read-in and written-out (3), then ... Load the maps for each species representing long-term habitat suitability Load the attributes of all the households as they were at the end of the spin-up (continue)

Update total livestock in each herd for each species, plus condition indices Update total livestock per person, plus running income for household Initially distribute livestock on landscape based upon suitability and access rules

For each month to be modeled, loop through ...

Input precipitation map, ensure that the ecosystem and household models sync Echo the month and year being modeled to the screen

For each week to be modeled, loop through ...

Distribute livestock on the landscape based upon suitability and access rules Read from the ecosystem model the amount of energy livestock acquired Update total livestock in each herd for each species, plus condition indices ... end weekly loop

Calculate energy used by livestock species, by age and sex cohorts in herds 


\section{call Livestock_Weight_Change}

call Livestock_Mortality call Livestock_Age_Herds call Livestock_Give_Birth

call Update_Agents

call Harvest_Crops

call Agent_Cash_Flows

call Agent_Cash_Needs

call Agent_Livestock_Trades call Agent_Energy_Flows call Agent_Livestock_Buying call Agent_Livestock_Gifting call Move_Herd_Camps

call Update_Agents call Agent_Outputs call Livestock_Outputs call Single_Herd_Out(10) call Individual_Agent_Outputs

call Spatial_Outputs call Monthly_Clean_Up if (month $==12$ ) then call Smooth_HSID nd if call Yearly_Clean_Up end do
Calculate weight change in livestock species, by age and sex cohorts in herds. If energy acquired is less than used, weight loss, otherwise, weight gain

Simulate death of livestock, within age and sex cohorts.

Age animals, if the month is appropriate for them to be aged

Simulate reproduction in livestock species, if the month is appropriate

Update total livestock per person, plus running income for household Harvest crops for each household. Yields are related to local precipitation Calculate incomes and expenses for each household

Estimate future needs for some select expenses, used to judge the need for livestock sales and purchases

Allow those households that wish to sell animals to do so

Calculate the energy needed and available, and purchase energy if needed

Allow those households that wish to purchase animals to do so

If households have lost all their animals, have a wealthy neighbor donate to them Allow households to consider whether to move their temporary camp to a new grazing location

Update total livestock per person, plus running income for household Output population summary information for all households simulated Output population summary information for the livestock species Output detailed information for herds of a single household, here household 10 Output summary information for selected households, usually those with observed household survey data, for later comparison to simulated data Output maps (e.g., habitat suitabilities, livestock densities, camp locations) Reset monthly accumulators to zero

If the month simulated is December, then ...

Create a smooth habitat suitability map for each species, for use in camp movement modeling

Reset yearly accumulators to zero

(continue)

Write the month and year being simulated to a file, for use in a graphic interface ... end monthly loop 
if (statev_flag $==1$.or. statev_flag $==3$ ) then call Save_HSID_Long_Term

call Save_Agents

end if

call Clean_Up

end program
If file from a spin-up is to written-out (1) or read-in and written-out (3), then ... Save the long-term habitat suitability maps for each species, used in movement modeling

Save the state of all the agents at the end of the simulation into a single file (continue)

Close the open files

End program DECUMA 
APPENDIX 4. The primary submodels of the DECUMA model, with descriptions. Submodels are generally sorted as they are called in DECUMA (Appendix 3), with duplicates and trivial processes not shown. Looping applied to groups of statements is indicated, except for implied looping across landscape cells. Most accumulators are not cited explicitly, but are listed in the output submodels.

\section{Initialize_Values}

Set random seed (non-looping).

Input simulation parameters (e.g., pathways, map names, months to model) (non-looping).

\section{Initialize_Metrics}

Input parameters common across households, shown in Appendix 2 (non-looping).

\section{Initialize_Landscapes}

Read in maps describe the cells comprising the landscape: Study area; Household density;

Subareas; Group ranches; Slope; Dry season distance to water; Transition season distance to water; Wet season distance to water; Force map, helping define access to grazing areas by livestock (non-looping).

\section{Initialize_Livestock}

For each species

Read in initial gender-specific age density distribution. These are proportions, one value for each age cohort, for the species in question. They are used to distribute livestock herds of a given size into specific age cohorts.

Read in population parameters: Month of birth; Effect of condition index on birth rate; Effect of condition index on death rate; Female and male intrinsic survival rates; Birthing rate; Female and male Tropical Livestock Unit equivalents (see Methods); Female and male probability to sell; Female and male probability to buy.

Read in energy parameters: Minimum and maximum body mass ratios, used in setting 0 and 1 endpoints for body condition indices; Female and male lean mass and Brody curve parameters, yielding expected masses; Maximum body mass loss and gain rates; Basal energy use; Voluntary energy use; Gestation costs; Lactation costs; Thermal costs; Travel costs.

\section{Initialize_Houses}

For each household

Read and initialize attributes for households, in the Kajiado application including 3820 files similar to the example in Appendix 1. In that application, 184 of the households were observed, the remainder were located stratified randomly using methods described in the manuscript. 
Initialize_Herds

For each household

For each species

Distribute initial livestock holdings (read in under Initialize_Houses) to the appropriate age cohorts in the Leslie matrix (see Methods), using the initial age proportion distribution read in under Initialize_Livestock.

Assign expected body masses for each age cohort in each sex. This uses Brody curves (i.e., expected weight $=$ lean mass $*(1-\exp (B))$, where B equals $(-1 * \beta)$

* (Current age / Maximum age). Here $\beta$ is a species specific parameter (see Methods for citations by Leslie) and ages are in days.

For each household

Calculate tropical livestock units owned by the house, given livestock holdings and equivalents read in under Initialize_Metrics.

Calculate veterinary expenses, based on household specific veterinary expenses (e.g., Appendix 1) and current tropical livestock units owned.

Restore_HSID_Long_Term

For each species

Reads long-term habitat suitability index maps, one for each species, if the user has requested that those be saved in a preliminary spin-up simulation. These maps are used by household herders when deciding whether to move their temporary camps. These maps capture long-term expected forage production, which herders consider when making decisions regarding movement. In decision making, the households consider both long-term expected suitability and short-term forage availability, and weight the expected benefits against the costs of moving.

Restore_Agents

For each household

Reads in all state variables for individual households, using a file created during a preliminary spin-up simulation. The states of households are restored to the condition they were in prior to the termination of the spin-up simulation.

\section{Livestock_Update_Summarize}

For each household

For each species

For each sex

Recalculates body mass condition indices, comparing simulated and expected masses.

Updates total herd sizes, given the numbers of animals in the age cohorts.

\section{Livestock_Distribute}

For each species

Read habitat suitability index maps from the ecosystem model.

Convert habitat suitability indices and density parameters per $\mathrm{km}^{2}$ (Appendix 2) to maximum tropical livestock units per landscape cell.

Add habitat suitability indices to long-term suitabilities (see Restore_HSID_Long_Term). 
Random household order, used to randomize the order herders select grazing lands (nonlooping).

For each household

For each species

Based on habitat suitability and values in force maps, locate the best grazing location (i.e., landscape cell) within a defined grazing orbit (Appendix 2) around the current location of the permanent household or temporary camp.

Place the animals in the best grazing area identified for that species.

If a landscape cell has reached capacity, and no more animals can be placed there, place animals on second-best or third-best landscape cells within the grazing orbit (up to 10 subherds modeled).

For each species

Write-out the landscape map with total numbers of animals per landscape cell. These maps include numbers of animals on cells across all households, and are used by the ecosystem model to simulate grazing.

\section{Livestock_Energy_Acquired}

For each species

Read energy acquired by all the animals of a given species grazing in the distribution derived (see Livestock_Distribute), in units of $\mathrm{MJ}_{\text {animal }}{ }^{-1}$ day $^{-1}$.

For each household

For each species

Calculate average energy acquired for animals of a given herd across all subherds (see Livestock_Distribute). This yield a measure of the average metabolizable energy ( $\mathrm{MJ}$ animal $^{-1}$ day $^{-1}$ ) acquired by each herders animals in the distribution simulated.

\section{Livestock_Energy_Used}

For each household

For each species

For each sex

Zero-out accumulators of energy used.

Calculate average body mass.

Calculate average body condition index.

Calculate baseline energy use, reflecting basal metabolism, i.e., $\mathrm{E}=$ average mass * basal energy use, yielding $\mathrm{MJ}$ animal ${ }^{-1}$ day $^{-1}$ here and in what follows.

For each household

\section{For each species}

Calculate the effect of condition indices on voluntary energy use, VCI. Animals with poor body condition can conserve energy by resting. A linear regression between condition index and parameters reflecting the effect of condition on energy use is used.

Calculate total travel to acquire water, using current locations of animals and distantto-water maps (see Initialize_Landscapes).

Calculate average slope of lands grazed by animals. 
Calculate vertical travel distance, $\mathrm{V}=$ horizontal distance * (average slope / 2.), given that half the travel is up-slope.

Calculate effect of horizontal travel $\mathrm{H}=$ horizontal distance * average body mass * horizontal travel costs per $\mathrm{km}$.

Calculate effect of vertical travel VT $=$ vertical distance $*$ average body mass * vertical travel costs per $\mathrm{km}$.

Adjust horizontal travel cost to incorporate voluntary energy savings, $\mathrm{H}=\mathrm{H} *$ VCI.

Adjust vertical travel cost to incorporate voluntary energy savings, VT $=\mathrm{VT} * \mathrm{VCI}$. Calculate snow depth (note: snow modeling was not used in Kenya) (non-looping) For each species

Calculate effect of snow depth on species, given brisket height.

For each household

For each species

Calculate effect of snow on travel costs, if snow depth $<0.3$, then $\mathrm{S}=(0.71 *$ effect on species * $\exp (0.019 *$ effect on species $)) / 100$, else $\mathrm{S}=(1.23 *$ effect on species $* \exp (0.0223 *$ effect on species $)) / 100$. (Parker et al. 1984).

Adjust effect of horizontal travel to include snow, $\mathrm{H}=\mathrm{H} * \mathrm{~S}$.

Adjust effect of vertical travel to include snow, $\mathrm{VT}=\mathrm{V} * \mathrm{~S}$.

Calculate lactation cost, if a month of lactation, $\mathrm{L}=$ basal energy use * average body mass * lactation cost.

Adjust lactation cost to include only the portion of the herd that is lactating. DECUMA uses the number of suckling animals to reflect that: $\mathrm{L}=\mathrm{L} *$ (newborns / total herd size).

Calculate gestation costs, if a month of gestation, $\mathrm{g}=0.000024 *$ ( ( gestation month * 100 )**3.13 )/ 100. (Hobbs 1985).

Calculate effect of gestation, $\mathrm{G}=\mathrm{g} *$ basal energy use * average body mass.

Calculate the total number of pregnant animals, based on condition indices and its effect on birthing rates, pregnant $=$ pregnancy rate $*$ total number of females.

Adjust effect of gestation based on pregnancy: $G=G^{*}$ pregnant / total herd size.

Calculate thermal energy costs, $\mathrm{T}=$ average degrees * (cost per degree when active * proportion active) * (cost per degree when bedded * proportion bedded) (Note: not used in Kenya, as temperature is above critical temperature).

Calculate effect of temperature: $\mathrm{T}=\mathrm{T} *$ basal energy used $*$ average body mass.

Calculate voluntary costs, tied to condition indices: $\mathrm{V}=$ (maximum energy used basal energy used) * average body mass * VCI.

Calculate total energy used: energy $=\mathrm{E}+\mathrm{G}+\mathrm{L}+\mathrm{T}+\mathrm{H}+\mathrm{VT}+\mathrm{V}$, or basal, gestation, lactation, thermal, horizontal travel, vertical travel, and voluntary energy costs.

\section{Livestock_Weight_Change}

For each household

\section{For each species}

Compare energy acquired (see Livestock_Energy_Acquired) to energy used (Livestock_Energy_Used), and knowing energy required to gain or loose $1 \mathrm{~km}$ (26 MJ net energy per kg, Coppock et al. 1983), covert to change in $\mathrm{kg}$, then daily value to change per month, i.e., *365/12. 
Trim body mass change to not exceed a maximum gain, or maximum loss.

Apply change in body mass to all age cohorts, not allowing cohorts to exceed a maximum, or fall below a minimum, body mass.

\section{Livestock_Mortality}

For each household

For each species

For each age

\section{For each sex}

Calculate monthly death rate correction based on body condition index, and coefficients reflecting the effect of condition indices on death rate. A linear regression is used to yield an adjustment (0.-1.) on death rates due to body condition.

Calculate monthly death rate, based on intrinsic survival probability (read in under Initialize_Livestock) and increased by the effect of body condition index on death rate.

Decrement cohort, removing dead animals.

\section{Livestock_Age_Herds}

For each household

For each species

For each age

\section{For each sex}

If the month is designated to when animals are aged (e.g., December), then shift animals in each cohort to the next year in the matrix.

Correct body mass to reflect the current body condition index of the animal, relative to the expected body mass of the animal's new age. If this is not done, animals essentially loose body mass simply by aging. That is, even if they are at exactly expected body mass at year $\mathrm{N}$, as they move to year $\mathrm{N}+1$, they would likely be below expected body mass.

Zero-out cohort matrix cells, condition indices, and body masses for newborns. They will be restored in Livestock_Give_Birth.

\section{Livestock_Give_Birth}

For each household

For each species

For each age

\section{For each sex}

If it is a designated birth month for the species, then calculate monthly birth rate correction based on body condition index, and coefficients reflecting the effect of condition indices on birth rate. A linear regression is used to yield an adjustment (0.-1.) on birth rate due to body condition.

Calculate births, based on intrinsic birth rates per age cohort (read in under Initialize_Livestock) and multiplied by the effect of body condition index on birth rate. 
Fill cohort matrix cells with new births. Animals are initialized to be healthy, as females will take their own systems to benefit offspring.

Update_Agents

For each household

Calculate household adult equivalents (see Methods), $\sum$ number in age-sex class * adult equivalent (Note: Done for completeness, but redundant when called each month. This version of DECUMA does not modify household composition).

Calculate household energy requirement, $\sum$ number in age-sex class * calories required * days in month (Note: Done for completeness, but redundant when called each month. This version of DECUMA does not modify household composition).

For each household

For each species

For each sex

Update tropical livestock units owned by household: $\sum$ number of animals * tropical livestock units per animal.

For each household

Calculate tropical livestock units per human adult equivalent.

Calculate a running income over the previous four month period.

Harvest_Crops

For each household

\section{For each crop}

If the month is one in which crops (here, maize, beans, onions, or tomatoes) should be harvested, then calculate accumulated rainfall in the previous months (see Appendix 1 for harvest and rainfall accumulation flags).

Calculate yield per ha, using accumulated rainfall and a linear regression relating rainfall and yield using coefficients (see Appendix 2).

Calculate total yield in metric tons per ha, in the current application for rainfed (e.g., $=$ yield per ha), irrigated (e.g., = yield per ha $* 2.0+0.5)$ and Loitotitok rainfed (e.g., = yield per ha $* 1.4$ ), with multipliers crop specific and based on household survey results, and with those for maize shown.

Calculate total harvest for the crop by summing the three production types (Note: not all crops are grown in each system (rainfed, irrigated, Loitokitok rainfed). For example, maize is not irrigated, onions and tomatoes are).

Add stored harvest to the current harvest to yield a total available (Note: Onions and beans are not stored long-term, but are sold).

\section{Agent_Cash_Flows}

For each household

Zero accumulators for harvests sold, assets, other income, etc. (for each: household).

For each household

For each crop

For each cropping system

Calculate crops sold, $\sum$ crop harvested * proportion sold * $(1 .-$ proportion going to partners). Partners are land owners who receive a portion of the harvested 
For each household

crop. Cropping systems include rainfed, irrigated, and Loitokitok rainfed in the Kajiado application.

Calculate total plant energy sold, based on total harvest that is sold and caloric values (see Appendix 2).

Calculate other income, $\sum$ wage income, livestock trading income, business income for the month (see Appendix 1).

Calculate total income, $\sum$ maize sold, beans sold, onions and tomatoes sold, other income, government leases income (Note: the last is not used in Kajiado).

Calculate total expenditures, $\sum$ tea and sugar, general and school fees, crop inputs, veterinary care per tropical livestock unit owned (see Appendix 1).

Calculate assets, $\sum$ new cash in, cash box.

If assets $>$ expenditures, pay all expenses, add the surplus to net income.

Otherwise, if assets $>$ tea and sugar, purchase tea and sugar, important for all households, and decrement from assets.

If remaining assets $>$ veterinary costs, pay for veterinary costs, and decrement from assets.

If remaining assets $>$ crop inputs, pay for crop inputs, and decrement from assets.

If remaining assets $>$ general expenses and school fees, pay for general expenses and school fees, and decrement from assets.

Agent_Cash_Needs

For each household

Calculate the income that can be anticipated over the next three months, $\sum$ wage income, livestock trading income, business income.

Add cash box to anticipated income, as it is a resource available (for each: household).

Calculate anticipated expenses for the next three months, $\sum$ tea and sugar, general and school expenses, crop inputs, veterinary costs.

Calculate the net need, as a positive value, anticipated income - anticipated expenses, and if the result is less than zero, change its sign.

\section{Agent_Livestock_Trades}

For each household

If anticipated cash needs (see Agent_Cash_Needs) exceeds a large value representing a trigger amount (see Appendix 2) and animals are owned, sell a large animal (i.e., cattle). Based on the probability of selling assigned to age-sex cohorts, and ensuring a cohort is not empty, identify an age-sex cohort from which to sell an animal.

Trade the animal, i.e., decrement cohort, decrement total animals, calculate meat expected based on condition of animal and based on that, accumulate total animal energy sold by household (for each: household), increment animals sold, add sale price to net income, cash box, and to income from species.

If anticipated cash needs (see Agent_Cash_Needs) exceeds a small value representing a trigger amount (see Appendix 2) and animals are owned, sell a small animal (i.e., goat or sheep). Based on the probability of selling assigned to age-sex cohorts, and ensuring a cohort is not empty, identify an age-sex cohort from which to sell an animal. The likelihood of selling a goat or sheep is calculated based on the ratio of 
the two species; the most common species owned by the household is most likely to be sold.

Trade the animal, i.e., decrement cohort, decrement total animals, calculate meat expected based on condition of animal and based on that, accumulate total animal energy sold by household (for each: household), increment animals sold, add sale price to net income, cash box, and to income from species.

\section{Agent_Energy_Flows}

\section{For each household}

Zero-out accumulators of energy gained.

Calculate average body condition index for females.

Calculate total number of calves, including calves that recently died and have cows that are still lactating.

Calculate milk production, adjusted for body condition of females, $=$ calves $*$ milk produced animal ${ }^{-1}$ day $^{-1}$, multiplied by an index from $0 .-1$. calculated using a linear regression of condition index and coefficients relating that to milk production.

Convert milk production to total milk energy, milk production * caloric content * days in month.

If milk energy $>$ energy required by household, sell surplus and consider energy requirements to have been met. Increment milk income, cash box, net income, income from selling by the value of the milk sold.

Otherwise, milk energy equals milk energy acquired.

Calculate energy acquired from sugar in tea. Used regardless of need.

For each species

\section{For each age}

Calculate average condition index

Calculate expected meat from animals given their condition indices, and a linear regression relating condition index to meat produced (see Appendix 2).

Calculate meat energy acquired, $\sum$ meat per animal $*$ deaths $*$ proportion dead that are edible * caloric content.

\section{For each species}

Add to meat energy acquired that from animals slaughtered as part of ceremonies.

\section{For each household}

Calculate total meat energy used by household, trimming to a maximum amount $(30 \%)$ of total requirements.

If needs have not already been met, calculate energy from other crops ( $\sum$ onions, tomatoes $\mathrm{kg}$ * caloric content), and subtract what is used from those stored crops. Do these first, in that they will not store as well as maize.

If beans remain in storage, and household needs have not yet been met, calculate energy used from beans ( $\mathrm{kg} *$ caloric content), and subtract what is used from the stored beans.

If maize remains in storage, and household needs have not yet been met, calculate energy used from maize ( $\mathrm{kg} *$ caloric content), and subtract what is used from the stored maize. 
Calculate the total energy used by the household, and determine if maize should be purchased, $\sum$ milk energy, meat energy, maize energy, bean energy, other crop energy, sugar in tea energy.

If energy is still required, and the cash box is not empty, buy the maize needed, or as much as the household can afford. Decrement cash box and net income by the cost of the maize.

If energy is still required after consuming purchased maize, that is assigned as gifted supplemental energy.

\section{Agent_Livestock_Buying}

For each household

If the household cashbox exceeds cash needs (see Agent_Cash_Needs) by more than an assigned large trigger (see Appendix 2), purchase a large animal (e.g., cattle). Based on the probability of purchasing a given age-sex class (see Init_Livestock) and stratified random selection, purchase an animal of that type, increment cohort count, total herd count, set body condition to a mid-point (0.50), and body mass to an expected value. Decrement cash box by the amount spent on the animal.

If the household cashbox exceeds cash needs (see Agent_Cash_Needs) by more than an assigned smaller trigger (see Appendix 2), purchase a small animal (e.g., goat or sheep, selected randomly). Based on the probability of purchasing a given age-sex class (see Init_Livestock) and stratified random selection, purchase an animal of that type, increment cohort count, total herd count, set body condition to a mid-point (0.50), and body mass to an expected value. Decrement cash box by the amount spent on the animal.

Agent_Livestock_Gifting

For each household

\section{For cattle}

If household has lost all their animals, give a cow and a bull at least 3 years old. Locate the closest neighbor to the current camp location who has at least 50 cattle. Increment herd size for recipient, male count, female count, gifted animals keep their body masses and conditions as they had prior to gifting. Decrement herd size, female count, male count from household doing gifting.

\section{For goats}

If household has lost all their animals, give 3 female and 2 male one-year old or older animals.

Locate the closest neighbor to the current camp location who has at least 25 goats.

Increment herd size for recipient, male count, female count, gifted animals keep their body masses and conditions as they had prior to gifting. Decrement herd size, female count, male count from household doing gifting.

\section{For sheep}

If household has lost all their animals, give 3 female and 2 male one-year old or older animals.

Locate the closest neighbor to the current camp location who has at least 25 sheep. 
Increment herd size for recipient, male count, female count, gifted animals keep their body masses and conditions as they had prior to gifting. Decrement herd size, female count, male count from household doing gifting.

\section{Move_Herd_Camps}

Randomize the order households are processed, so that no household moves preferentially through the simulation (non-looping).

For each species

\section{For each household}

Randomly select from throughout the study area 10 areas as possible sites to move to.

Calculate for each potential site: number of tropical livestock units already grazing at that location, distance to permanent household, distance to current camp, shortterm (current month) habitat suitability and grazing orbit, whether in or outside of group ranch, and long-term habitat suitability.

Assign a score to each of the measures of the site, often using linear regression of the measure and coefficients relating that measure to a score from 0 to 1 (see Appendix 2 for coefficients). In some cases (i.e., being inside or outside the household's group ranch, plus force map values), coefficients are assigned directly, without regression.

Adjust the scores by a measure reflecting a resistance to moving, score $=$ score resistance, reflecting the costs associated with moving camps.

Adjust the scores by a measure reflecting a desire to return to the permanent household location, score $=$ score + desire to return .

Considering the current location of the household and the 10 alternatives, identify the site with the highest score. In the wet season, very high scores on the probability of returning to the permanent household location make that very likely, as observed in the system. With this approach, households may stay or may move.

If the household moves, increment a counter accumulating moves. Add the tropical livestock units owned by the household to the density map used when assigning scores that influence stocking on movement decision making (i.e., step 2 in this section).

\section{Agent_Outputs}

Calculate average responses for the households simulated. These are responses across all households in the simulation (non-looping).

Write to an output ASCII file household energy results for the month: energy acquired, milk energy consumed, own grain energy consumed, bought grain energy consumed, meat energy consumed, plant energy consumed, other energy consumed, relief energy consumed, milk energy sold, plant energy sold, animal energy sold (non-looping).

Write to an output ASCII file household harvest results for the month: rainfed maize harvest, irrigated maize harvest (always zero), Lotokitok rainfed maize harvest, rainfed bean harvest, irrigated bean harvest (always zero), Lotokitok rainfed bean harvest, rainfed onion and tomato harvest, irrigated onion and tomato harvest, Loitokitok rainfed onion and tomato harvest, total maize harvest, total bean harvest, total onion and tomato harvest, maize sold, beans sold, onions and tomatoes sold, cash for maize sold, cash for 
beans sold, cash for onions and tomatoes sold, maize in storage, beans in storage, onions and tomatoes in storage (non-looping).

Write to an output ASCII file household cash flows for the month: net income, cash income, income selling, other income, cash to buy food, cash to buy animals, running income per adult equivalent, cash needs, cash box, expenditures, debt, cattle income, goat income, sheep income (non-looping).

Write to an output ASCII file other results from households for the month: energy required, adult equivalents, tropical livestock units, tropical livestock units per adult equivalent, the proportion of food requirements met by the households own products, the proportion of food requirements met in total, cattle sold, goats sold, sheep sold, cattle bought, goats bought, sheep bought, cattle gifted, goats gifted, sheep gifted, total milk sold, remaining milk (non-looping).

\section{Livestock_Outputs}

Calculate responses for livestock herds owned by the households simulated. These are responses across all households in the simulation. Most are totals across all households, but some are averages and indicated below (non-looping).

For each species

Write to an output ASCII file livestock information for the month: number of herds, average number of subherds, number of animals, number of females, number of males, number of juveniles, number of non-breeding females (e.g., heifers), number of non-breeding males, number of adult females, number of adult males, average condition index, average female condition index, average male condition index, number of deaths, number of female deaths, number of male deaths, number of juvenile deaths, number of non-breeding female deaths, number of non-breeding male deaths, number of adult female deaths, number of adult male deaths, average energy acquired (non-looping).

\section{Spatial_Outputs}

Write to an output file in GRIDASCII format the number of households in each landscape cell (non-looping).

Write to an output file in GRIDASCII format the number of camp in each landscape cell (non-looping).

For each species

Write to an output file in GRIDASCII format the number of animals in each landscape cell (non-looping).

Write to an output file in GRIDASCII format the habitat suitability index of households in each landscape cell (non-looping).

Single_Herd_Out

For each species

For each age

For each sex

Write to an output ASCII file values for the month representing: total number, body mass, expected body mass, body condition index (non-looping). 


\section{For each species}

Write to an output ASCII file information about subherds: camp x location, camp y location, subherd identifier, subherd $\mathrm{x}$ location, subherd y location, number in subherd (non-looping).

Write to an output ASCII file livestock information for the month: number of females, number of males, number of animals, average female condition index, average male condition index, average condition index, juvenile deaths, female non-breeding deaths, male non-breeding deaths, female adult deaths, male adult deaths, energy used, energy acquired (non-looping).

\section{Individual_Agent_Outputs}

Write to an output ASCII file general household information: household identifier, x UTM, y UTM, $\mathrm{x}$ in cell units, $\mathrm{y}$ in cell units, adult equivalents, net income, cash box, tropical livestock units, tropical livestock units per adult equivalent, running income, running income per adult equivalent, number of cattle, number of goats, number of sheep, cattle condition index, goat condition index, sheep condition index, cattle deaths, goat deaths, sheep deaths, cattle sold, goats sold, sheep sold, cattle bought, goats bought, sheep bought, cattle gifted, goats gifted, sheep gifted, maize harvested, beans harvested, onions and tomatoes harvest, maize in storage, beans in storage, onions and tomatoes in storage, milk energy, grain energy grown by the household, meat energy, plant energy, other energy, grain energy bought, gifted and relief energy, milk energy sold, plant energy sold, animal energy sold (non-looping).

For each species

Write to an output ASCII file information about the household camp: permanent

household $\mathrm{x}$ location, permanent household y location, camp x location, camp y location, number of movements during the year (non-looping).

Write to an output ASCII file about household energy: adult equivalents, tropical livestock units per adult equivalents, energy required, percent of requirements filled by different products (i.e., milk, grain grown by the household, beans, onions, and tomatoes grown by the household, meat, other sources, bought grain, and relief), maize in storage, beans in storage, onions and tomatoes in storage, milk energy sold, plant energy sold, animal energy sold, cash box (non-looping).

\section{Smooth_HSID}

Zero-out a smooth habitat suitability surface, which stores smoothed long-term habitat suitability indices, used in deciding camp movements by households (non-looping).

Across the landscape, calculate the average long-term habitat suitability, smoothing over a set distance (here, $20 \mathrm{~km}$ ) (non-looping).

\section{Save_HSID_Long_Term}

Write to an output file in GRIDASCII format a set of values storing long-term habitat suitability indices, one per landscape cell. This map may be read in (see Restore_HSID_Long_Term) at the beginning of a simulation, allowing a spin-up simulation to be run, and scenario analyses to continue from the end of that simulation (non-looping). 


\section{Save_Agents}

Save the state of the simulation, used as a bookkeeping tool, so that simulation results may be related to simulation parameters at later dates. These data are also used when a state variable file is stored system (see Restore_Agents), with household data appended, so that the household results and the settings used in the simulation are never separated. Information written include: landscape cell size, study area width, study area height, number of livestock species, number of crop species, number of households, application pathway, household file pathway, household file root name, map names (i.e., household density, study area, slope, distance to water in the dry, transitional, and wet seasons, group ranch, force map), and the entire contents of the parameter file shown in Appendix 2 (non-looping).

For each household

Append to the simulation parameter ASCII file the state of the household, to be used during later simulations to initialize the system (see Restore_Agents). Information written include: household identifier, cash box, debt, running income, maize in storage, beans in storage, onions and tomatoes in storage.

For each household

For each species

For each age

Append to the simulation parameter ASCII file the state of household animals, including: number of females, female body mass, number of males, male body mass. 